\title{
La subsanación en la acreditación de méritos en procesos selectivos del personal al servicio de las administraciones públicas ${ }^{1}$
}

\author{
Federico A. Castillo Blanco \\ Catedrático de Derecho Administrativo \\ Universidad de Granada.
}

\section{INTRODUGGIÓN: EL ESTADO DE LA GUESTIÓN}

El presente trabajo aborda el tema de la posibilidad o no de subsanación de documentos aportados como méritos por los participantes en procesos selectivos. Documentos aportados que, sin embargo, no reúnen todos los requisitos requeridos por las Bases de la Convocatoria. Ese es, en principio, el objeto del mismo, pero lo cierto es que más allá de ello y si horadamos hasta el fondo del asunto veremos que nos encontramos en un nuevo supuesto en que principios constitucionales como el de justicia material y eficacia en el actuar administrativo vuelven a ser enfrentados en un supuesto concreto de aplicación del ordenamiento jurídico. ${ }^{2}$

Pero también podremos observar cómo la casuística en que se desenvuelve la doctrina jurisprudencial emitida por nuestros tribunales, prácticamente en todos los niveles jurisdiccionales del orden contencioso-administrativo, se hace acreedora en ocasiones del calificativo de contradictoria y, desde luego, pone de relieve, en ausencia de soluciones de lege ferenda y a pesar de la doctrina fi-

\footnotetext{
${ }^{1} \mathrm{El}$ presente trabajo es una versión modificada a estos efectos del publicado, en su momento, en el Libro Homenaje al Profesor Tomás Ramón Fernández.

2 Expresiva de esta tensión entre distintos principios es la STS de 4 de mayo de 2009 (rec. núm. 5279/2005) que expone que "En relación con lo que antecede, conviene subrayar que ciertamente los participantes en procesos selectivos están obligados a cumplir con las bases de la convocatoria y recae sobre ellos la carga de aportar la documentación en los términos que establezcan dichas bases, ya que así resulta conveniente para que el funcionamiento de esos procesos sea igual para todos los participantes y se desarrolle con la normal regularidad que exige el principio constitucional de eficacia administrativa (artículo $103 \mathrm{CE}$ ).

Pero debe destacarse también que esos criterios de racionalidad y proporcionalidad, que antes se han apuntado, no permiten valorar como incumplimiento de las repetidas bases aquellos comportamientos de los aspirantes que no respondan a una resistencia a observarlas, sino a una razonable duda sobre su significado o alcance. Cuando esto último suceda lo procedente será permitir subsanar el error inicial en que se pueda haber ocurrido."
} 
jada en interés de ley de la que seguidamente daremos cuenta, la carencia de suficientes criterios para resolver con una cierta coherencia los distintos supuestos que surgen a propósito del tema planteado.

En efecto. la jurisprudencia del Tribunal Supremo - véanse las SSTS de Sentencias de 28 de septiembre de 2010 y 11 de octubre de 2010- se ha venido pronunciando, en principio de forma favorable, sobre la aplicabilidad a los procesos selectivos del artículo 71 de la LPA siguiendo la doctrina en interés de Ley fijada por la Sentencia de 4 de febrero de 2003. La misma, por cierto, se ha reiterado en distintos pronunciamientos posteriores a ésta. Así, la STS de 25 de Octubre de 2012 (rec. 1417/2011), se pronunció en este sentido favorable a la concesión de plazo de subsanación para la mayor efectividad del derecho al acceso al empleo público; y en la misma línea, bien que un poco anterior, la STS de 4 de Mayo de 2009 (rec.5279/2005) avaló el criterio de la Sala de instancia favorable a que la Administración brindase plazo subsanatorio, pese a la cumplimentación errada de la casilla de solicitud en proceso selectivo, ya que la interpretación sistemática y lógica de las bases provocaba una situación de incertidumbre u oscuridad.

Pero como hemos apuntado la cuestión no acaba ahí. Y es que, a pesar de esa doctrina fijada, hay otros pronunciamientos jurisprudenciales que, si bien no hacen estrictamente caso omiso de la misma, realizan lo que bien pudiera llamarse una interpretación restrictiva del alcance del artículo 71 de la LPA en los procesos selectivos. Un ejemplo reciente lo tenemos en la Sentencia del Tribunal Superior de Justicia de Madrid de 14 de febrero de 2011 (recurso número $617 / 2009)^{3}$ y puede verse también, a título de ejemplo, la STSJ de Ma-

${ }^{3}$ La sentencia aborda el supuesto de un proceso selectivo, mediante el sistema de concurso-oposición, para el acceso a la condición de personal estatutario fijo en plazas de Celadores del Servicio de Salud de la Comunidad de Madrid. La recurrente participó en la convocatoria, y tras superar la fase de oposición, conforme a las Bases debía aportar en el plazo de quince días naturales la documentación acreditativa de los méritos que deseaba le fueran valorados en la fase de concurso.

A estos efectos, el apartado I.4 del Anexo II de dichas Bases establecía que sería objeto de valoración como experiencia profesional los servicios prestados en puestos, plazas ó empleos en centros públicos dependientes de las Administraciones Públicas no incluidos en otros apartados, siempre y cuando para su acceso se hubiese requerido una titulación académica igual ó equivalente a la exigida en la presente convocatoria. La demandante, dentro del plazo concedido al efecto, solicitó que le fuera tenido en cuenta como mérito un certificado de servicios de la Real Casa de la Moneda, Fábrica Nacional de Moneda y Timbre en que constaba que había prestado servicios en distintos periodos desde el año 2001 al año 2003.

La Administración, haciendo caso omiso de tal certificado, no valoró tal mérito en la valoración provisional primeramente efectuada, por lo que la recurrente reclamó en el plazo concedido al efecto aportando un certificado de la Real Casa de la Moneda, Fábrica Nacional de Moneda y Timbre en que constaban, además de los periodos en que había prestado servicios, la categoría con la que los había prestado 
drid de 14 de junio de 2010 (rec. núm. 278/2010) que resuelve las cuestiones que allí se plantean con similares criterios negando, en suma, la posibilidad de subsanación ${ }^{4}$.

en los diferentes periodos y la titulación requerida sin que la Administración atendiese dicha reclamación considerando que no se había presentado en plazo la misma con los requisitos establecidos en las Bases.

El Tribunal afirma en su sentencia que, en base a lo establecido en las bases, quien pretendiera la valoración del mérito debía de acreditar que se habían prestado servicios en puestos, plazas ó empleos en centros públicos dependientes de las Administraciones Públicas y que la titulación académica exigida para su acceso había sido igual ó equivalente a la exigida en la convocatoria, y concluye que ello no ocurrió en el caso que nos ocupa ya que únicamente constaba que había prestado servicios en distintos periodos pero sin constar el requisito de que la titulación académica exigida para ello había sido igual ó equivalente a la exigida en la convocatoria.

Argumenta, asimismo la sentencia referida, que el certificado originario presentado ni siquiera expresaba cuales habían sido los puestos de trabajo desempeñados, ni cual era su categoría, ni cual había sido la titulación académica que se le había exigido para acceder a ellos, por lo que la recurrente no acreditó en plazo que fuera un mérito valorable, haciéndolo tan solo con posterioridad, y fuera de plazo, al reclamar contra la falta de valoración del mérito que es cuando aportó un certificado de la Real Casa de la Moneda, Fábrica Nacional de Moneda y Timbre en que constaban, además de los periodos en que había prestado servicios, la categoría con la que los había prestado en los diferentes periodos y la titulación requerida, por lo que estima dicho tribunal que la resolución administrativa impugnada era conforme a derecho.

Y concluye, negando la aplicabilidad de cualquier procedimiento de subsanación, argumentando "que esta ausencia de presentación de la documentación en el plazo concreto establecido, y que no se olvide se fijó con claridad en la resolución por la que se hacía pública la convocatoria que nos ocupa, afectaba a aspectos materiales o de fondo resultando de imposible admisión trasladar un error propio a una Institución que ajustó su proceder, en todo momento, a la normativa vigente, máxime cuando se pretende obtener un trato privilegiado que tiene incidencia respecto a otros concursantes en el propio proceso selectivo y que podrían ver cómo, quien no ejercitó sus facultades de modo idóneo, podría, ahora, resultar adjudicatario de una plaza a la que ellos fueron acreedores al ajustar su proceder al mecanismo hecho público, con vulneración del derecho fundamental de igualdad en el acceso a la función pública, consagrado en los artículos 14 y 23.2 de la CE ".

${ }^{4}$ Que indica que "No estamos ante la carencia de requisitos en la solicitud de iniciación o falta de aportación de documentos preceptivos, sino de la aportación de méritos de forma voluntaria por cada uno de los solicitantes para ser valorados por la Comisión de Selección, de tal forma que no es posible conceder plazo de subsanación en supuestos como el presente, donde los méritos son presentados de forma voluntaria por los aspirantes y si son aportados tienen que documentarse en la forma prevista en las bases de la convocatoria, forma que vincula a todos los aspirantes en cuanto a las condiciones y plazo, no pudiendo, en contra del resto de solicitantes, conceder un plazo a la parte actora para que fuera del acto de presentación prevista pueda aportar la documentación que no aportó en su momento.

No se trata de que la solicitud no reúna los requisitos exigidos por la normativa aplicable y proceda su subsanación en el plazo de diez días. Se trata de un supuesto específico de obligación de aportar la documentación en que la parte basa sus méritos, es decir, no se trata de un documento imprescindible para la presentación al concurso, sin el cual no se admite al actor en el proceso selectivo, sino que estamos analizando la obligación de justificar documentalmente los méritos que los aspirantes alegan, méritos que no forman parte del contenido mínimo obligatorio de toda instancia, donde podría admitirse la subsanación prevista en el artículo 71 , sino de alegaciones voluntarias que corresponden a cada interesado y que está obligado a justificar documentalmente dentro del plazo de presentación de instancias....".

Revista Andaluza de Administración Pública

ISSN: 0034-7639, núm. 85, Sevilla, enero-abril (2013), págs. 75-105 


\section{EL ALGANGE DEL ARTÍCULO 71 DE LA LPA Y SU INGIDENGIA EN LOS PROGESOS SELEGTIVOS}

Como es suficientemente conocido el artículo 71 de la LPA, en su redacción actual, y tras la modificación operada en el mismo por la Ley 4/1999, establece en su apartado primero que si la solicitud de iniciación no reúne los requisitos que señala el artículo que lo precede en dicha Ley y los exigidos, en su caso, por la legislación específica aplicable, se requerirá al interesado para que, en un plazo de diez días, subsane la falta o acompañe los documentos preceptivos, con indicación de que, si así no lo hiciera, se le tendrá por desistido de su petición, previa resolución que deberá ser dictada en los términos previstos en el artículo 42 de la citada norma.

Añade, además, en su apartado segundo que siempre que no se trate de procedimientos selectivos o de concurrencia competitiva, este plazo podrá ser ampliado prudencialmente, hasta cinco días, a petición del interesado o iniciativa del órgano, cuando la aportación de los documentos requeridos presente dificultades especiales. Y sigue diciendo en el apartado tercero que, en los procedimientos iniciados a solicitud de los interesados, el órgano competente podrá recabar del solicitante la modificación o mejora voluntarias de los términos de aquélla. De ello se levantará acta sucinta, que se incorporará al procedimiento.

El artículo, que recordemos responde a un principio antiformalista en la tramitación de los distintos procedimientos ${ }^{5}$, tiene como objetivo principal, y

\footnotetext{
${ }^{5}$ Así resulta, por ejemplo, de los argumentos utilizados en la STS de 12 de abril de 1989 que expone, a estos efectos, que "El artículo 71 de la Ley de Procedimiento Administrativo obliga a la Administración a requerir al firmante de un escrito administrativo para que subsane la omisión de cualquiera de los requisitos del artículo 69, entre ellos el del inciso último del apartado a), esto es la acreditación de la representación. Y si se permite incluso la subsanación de la omisión de la firma, que es el requisito que expresa la asunción del contenido del escrito, y si, en efecto y por más sorprendente que parezca, es frecuente que, por ejemplo en las listas de admitidos y excluidos a la práctica de pruebas selectiva aparezcan los excluidos por falta de firma dándoles plazo para subsanar la omisión, no cabe imaginar que la falta de representación no pueda ser subsanada. Esta tesis de la Administración carece de fundamento alguno, contradice el citado artículo 71 de la Ley de Procedimiento Administrativo, y es contraria, además, al principio de tutela judicial efectiva de los derechos, el cual reduce al máximo las responsabilidades de cierre o preclusión de esa vía judicial por meros defectos formales. Es importante subrayar esto, a fin de dejar claro que la idea directriz que debe inspirar la interpretación de las normas procesales es la de que la actividad administrativa está sujeta al control de los jueces y que el acceso a ese control ha de ser facilitado y no entorpecido. Y esa idea directriz o matriz disciplinar es, a su vez, emanación de otra superior cual es la idea de la justicia, valor constitucional que en nuestro ordenamiento se resume en el derecho del particular a una justicia plenaria, la cual no puede verse ni retrasada -como aquí lo ha sido por culpa de una opo-
} 
ese es el espíritu que lo informa, favorecer la tramitación de las solicitudes y peticiones presentadas por los interesados a fin de evitar su archivo sin más trámite. Resultado, preciso es resaltarlo, que se anudaba a dicha situación en la legislación procedimental de 1958, o como resulta de la legislación actual la declaración del desistimiento del interesado que se ha de realizar por la correspondiente resolución administrativa.

Es de hacer notar que el artículo tiene como presupuesto para su aplicación que el escrito presentado por los interesados no reúna los requisitos establecidos en el artículo 70 de la Ley pero añade también, lo que es sumamente relevante respecto del caso objeto de estudio, que ha de reunir asimismo los que resulten de la legislación específica aplicable al caso concreto que es objeto de tramitación.

Pues bien, dichas previsiones han sido en principio, de forma reiterada, consideradas con carácter general aplicables a los procedimientos selectivos considerándose $^{6}$, no sólo una obligación de la Administración, sino también, y de forma expresa se ha señalado por la jurisprudencia, como un derecho inderogable de los interesados ${ }^{7}$.

sición administrativa carente de fundamento- ni mucho menos excluida por una arbitraria exacerbación de preocupaciones formalistas que lejos de servir al derecho lo anulan y destruyen".

${ }^{6}$ La STSJ de Canarias de 23 de julio de 2004 así lo afirma razonando que "....En consecuencia, resulta aplicable en la cuestión examinada el artículo 71 de la Ley 30/1992, como antes exigía el antiguo artículo 71 de la Ley de Procedimiento Administrativo en la redacción de 1958, pues se impone en ambos preceptos el deber de la Administración de requerir al interesado para que se subsanen las deficiencias cuando se aprecie que el mismo no cumple los requisitos que exige el ordenamiento en vigor y como señala en este punto el Ministerio Fiscal, la redacción del apartado segundo del artículo 71 excluye los procedimientos selectivos o de concurrencia competitiva para la ampliación prudencial hasta cinco días del plazo cuando la aportación presente dificultades especiales, luego si se prohíbe dicha ampliación, es claro que el precepto autoriza la concesión del plazo de diez días cuando se trate de un procedimiento selectivo de concurrencia competitiva, como es el caso planteado".

${ }^{7}$ Así lo argumenta la STS de 21 de octubre de 2004 que indica que "Del análisis del precepto, tras su modificación por la LMLRJPA puede deducirse que son dos los supuestos que habilitan y obligan a la Administración actuante para articular el requerimiento de subsanación en dicho precepto contemplado:

$1^{\circ}$ Cuando la solicitud de iniciación "no reúne los requisitos" que se señalan en el artículo 70 LRJPA, anterior, de forma pormenorizada.

$2^{\circ}$ Cuando con la solicitud de iniciación no se acompañan "los documentos preceptivos".

Esto es, la concurrencia de alguno de los dos supuestos es los que, como hemos expresado, habilita y obliga a la Administración actuante para, imperativamente, facilitar al administrado el trámite de subsanación, el cual, en consecuencia, se configura como:

a) Un derecho inderogable de todo particular en relación a cualquier procedimiento administrativo; y, consecuentemente,

b) Una obligación de la Administración. 
Lo cierto, sin embargo, a pesar de lo expuesto y como más atrás hemos puesto de relieve, es que si bien no se niega en forma expresa la posibilidad de subsanación en estos procedimientos, y más específicamente respecto de los requisitos para tomar parte en el proceso selectivo ${ }^{8}$, no se encuentra idéntica unanimidad jurisprudencial cuando se trata de delimitar el alcance de la subsanación en relación a los méritos alegados en un procedimiento selectivo cuando el sistema utilizado es el concurso o el concurso oposición. En estos supuestos, es posible encontrar resoluciones jurisdiccionales que transitan en distintas direcciones. La discusión se va a centrar en si alcanza o no a los méritos alegados defectuosamente pero, en el fondo del asunto, el debate que se plantea lo es respecto de en qué medida el principio de igualdad queda afectado como consecuencia de la realización de tal trámite subsanatorio y si esos intereses encontrados han de solucionarse a favor de la prevalencia de los principios de eficacia y seguridad jurídica o, por el contrario, debe de pre-

Por otra parte el contenido y mandato del presente se nos presenta plenamente conforme y coordinado con el reconocimiento que de los denominados Derechos del ciudadano, en sus relaciones con las Administraciones Públicas, se efectúa en el artículo 35 de la citada LRJPA."

${ }^{8}$ Muestra de ello es la STSJ de Extremadura de 25 de octubre de 2005 que razona que "Frente a ello, no es posible subsanar la omisión de falta de documentos esenciales para resolver el procedimiento selectivo, puesto que toda la documentación acreditativa de los méritos tenía que adjuntarse junto con la instancia en el plazo de veinte días naturales, siendo únicamente valorables los méritos que acrediten los interesados. En lo que se refiere a la posibilidad de haber concedido por parte de la Administración el plazo de subsanación previsto en el artículo 71.1 de la Ley 30/92, de 26 de noviembre -no el del artículo 80 que se refiere a la apertura de un proceso probatorio y que no es aplicable en un proceso selectivo que no exige dicho trámite de prueba-, es necesario señalar que no se trata de una carencia de requisitos en la solicitud de iniciación o falta de aportación de documentos preceptivos, sino de la aportación de méritos de forma voluntaria por cada uno de los solicitantes para ser valorados por la Comisión de Selección, de tal forma, que no es posible conceder plazo de subsanación en supuestos como el presente, donde los méritos son alegados de manera voluntaria por los aspirantes y si son alegados, tienen que documentarse en la forma prevista en las bases de la convocatoria y referirse a los servicios de fontanero que eran los únicos objeto de valoración en atención a la plaza convocada, forma que vincula a todos los aspirantes en cuanto a las condiciones y plazo, no pudiendo, en contra del resto de solicitantes, conceder un plazo al actor para que fuera del plazo de presentación de instancias, plazo máximo para aportación de méritos, pueda aportar la documentación que no presentó en su momento. Debemos insistir en que a diferencia de lo expuesto por la parte demandante no estamos aquí ante un supuesto donde la solicitud no reúne los requisitos exigidos por la normativa aplicable y procede su subsanación en el plazo de diez días, conforme a lo dispuesto en el artículo 71 de la Ley 30/92, de 26 de Noviembre, sino ante un supuesto específico de obligación de aportar la documentación en que la parte basa sus méritos, es decir, no se trata de un documento imprescindible para la presentación al concurso, sin el cual no se admite al actor en el proceso selectivo, sino que estamos analizando la obligación de justificar documentalmente todos los méritos que los aspirantes mencionan en sus instancias, méritos que no forman parte del contenido mínimo obligatorio de toda instancia, donde podría admitirse la subsanación prevista en el artículo 71, sino de alegaciones voluntarias que corresponden a cada interesado y que está obligado a justificar documentalmente dentro del plazo de presentación de instancias." 
valecer el principio de justicia material. Este, en realidad, es el tema objeto de discusión ${ }^{9}$.

No se trata, ha de aclararse e insistir en ello para delimitar el verdadero alcance del tema que nos ocupa, de méritos presentados fuera del plazo establecido en las bases de la convocatoria lo que no parece suscitar la menor duda ya que dificilmente puede subsanarse lo no presentado en el tiempo establecido, y toda vez que en este supuesto si que el principio de igualdad, que ha de seguirse en la instrucción de cualquier procedimiento de conformidad con lo dispuesto en el artículo 85.3 LPA, vedaría dicha posibilidad y no parece que a ello alcance la doctrina legal establecida en la STS de 4 de febrero de 2003 a la que más adelante nos referiremos ${ }^{10}$. Ni siquiera, nótese, a la presentación de nue-

${ }^{9}$ Éste es el principal argumento manejado por la STSJ de Andalucía de 15 de junio de 2009 (Sala de Granada, rec. núm. 1948/03) que expone que "La subsanación no puede extenderse a la documentación cuya presentación viene exigida de modo inexcusable para acreditar el mérito cuya valoración se pretende en la autobaremación, tal y como se expresa la base 3.3 y que fue omitida.

La aportación de los documentos omitidos junto a la solicitud es una carga que pesa sobre el que quiere participar quien con su petición se acoge a la convocatoria de tal manera que su falta da lugar a que si el mérito no ha sido alegado, acreditado documentalmente y autobaremado por el aspirante, no tendrá lugar su valoración, pues no podrá tenerse en cuenta los obtenidos o alegados o no autobaremados (como es el caso de uno de los notables obtenidos por la actora) con posterioridad a la finalización del plazo de presentación de solicitudes pues en este tipo de procedimientos que son de concurrencia competitiva es de especial importancia garantizar el principio de igualdad entre todos y cada uno de los participantes, que no sería respetado si a quien no acredita un mérito le dan la posibilidad de hacerlo después del plazo de presentación de instancias, ya que va a ser objeto de un trato de favor frente a los demás que han cumplido las bases de la convocatoria".

Frente a dicha posición la STSJ de Castilla-La Mancha de 12 de enero de 2009, recurso 158/2005 que si bien argumenta que, en la relación bilateral entre la Administración y un particular, en ocasiones resulta posible flexibilizar las exigencias formales y atender a la materialidad de las cosas, en procesos competitivos, el cumplimiento estricto de los deberes procedimentales por parte de los aspirantes es clave en la viabilidad del sistema, y existe el derecho de quien los ha cumplido de exigir que no se tolere su incumplimiento por parte de terceros, admite la subsanación oportuna del mérito alegado en tiempo ya dicho supuesto no afecta al principio de igualdad pues el mismo es claramente diferente de aquel en que un aspirante pretende que se le valore un mérito que alega y justifica fuera del plazo establecido en las bases de la convocatoria, supuesto que sí resulta contradictorio al principio de igualdad.

${ }^{10}$ Así lo subraya la STSJ de Galicia de 26 de octubre de 2005 que dice: “...De las disposiciones generales sobre los procedimientos administrativos, queda desplazada por las bases del concurso como razona la juzgadora de instancia a la hora de rechazar la apelación que las actoras hacen en la instancia a la posibilidad que ofrece el artículo 71 del Texto Legal citado relativa a la Subsanación y mejora de la solicitud, pues las prerrogativa que otorga tiene por finalidad la enmienda de defectos, omisión de datos y errores por el interesado y la obligación de la Administración de ponerlo en su conocimiento, señalando aquellos y concediendo plazo de diez días a los efectos indicados, con la advertencia de que de no proceder en este sentido, se le tendrá por desistido de su petición. El propio Tribunal Supremo se encarga de hacer notar que este precepto y lo que permite, no es aplicable para suplir la falta de presentación de la documentación exigida en el plazo establecido para ello pues se estarían inobservando las bases y propiciando la desigualdad entre los participantes en un proceso selectivo...". 
vos documentos para ser objeto de valoración en el plazo de subsanación establecido tras la aprobación provisional de admitidos a un Concurso-Oposición en concepto de subsanación y mejora de la solicitud ${ }^{11}$.

El debate y la controversia que será objeto de comentario, subrayémoslo, se centra en la posibilidad de subsanar que eventualmente habría de concederse, por expresa disposición del artículo 71 de la LPA, cuando presentados los documentos, acreditativos de méritos valorables en la fase de concurso de un proceso selectivo, éstos no reúnen todos los requisitos establecidos en las Bases, si bien es cierto que de los mismos si resulta, y aquí está una de las claves del problema planteado, la eventual existencia del mérito alegado.

\section{LA DOGTRINA DEL TRIBUNAL SUPREMO SOBRE LA SUBSANACIÓN DE DEFEGTOS Y REQUISITOS EN LOS PROCESOS SELEGTIVOS}

Antes de referirnos a la doctrina recaída en interés de ley sobre el aspecto concreto de la cuestión objeto de análisis, realizaremos, a grosso modo y sin la intención de ser exhaustivos, un rápido acercamiento sobre los parámetros frecuentemente utilizados por nuestra jurisprudencia a la hora de abordar las distintas cuestiones que se plantean en torno al desenvolvimiento y desarrollo de los procesos selectivos y que, además, tienen una especial incidencia en el caso planteado.

\section{Breve síntesis de la doctrina jurisdiccional y constitucional so- bre los procesos selectivos.}

En primer lugar, cabe citar en cuanto al contenido constitucional previsto en el artículo 23.2 de la CE, que el tribunal constitucional ha dejado claramente establecido que nos encontramos ante un derecho a la predeterminación normativa del procedimiento de acceso a las funciones públicas con los requisitos que señalen las Leyes (por todas en las SSTC 73/1998, de 31 de marzo y 138/2000, de 29 de mayo), pues la Constitución reserva a la Ley, y, en todo caso, al principio de legalidad, la regulación de las condiciones del ejercicio del derecho, lo que entraña una garantía de orden material que se traduce en la imperativa exigencia de predeterminar cuáles hayan de ser las condiciones para acceder a la función pública, de conformidad con los principios constitu-

\footnotetext{
${ }^{11}$ Puede verse, a este respecto, la STSJ de Madrid de 29 de julio de 2010 (rec. núm. 339/2009).
} 
cionales de igualdad, mérito y capacidad, que sólo pueden preservarse y establecerse mediante la intervención positiva del legislador.

El ulterior control jurisdiccional contrasta, por tanto, si la actuación administrativa se ha ajustado o no a las condiciones de igualdad, mérito y capacidad previamente establecidas, pues «la fijación ex ante de los criterios de selección, tanto de carácter absoluto como relativo, en que consistan la igualdad, mérito y capacidad para cada función es la única forma de que pueda ejercerse el derecho mismo» ( STG 48/1998, de 2 de marzo, F. 7 .b) ${ }^{12}$.

Inicial consideración que ha sido completada por la también conocidísima doctrina del Tribunal Constitucional según la cual el artículo 23.2 CE impone la obligación de no exigir para el acceso a la función pública ningún requisito o condición que no sea referible a los conceptos de mérito y capacidad. Con la precisión, parece relevante hacerlo notar, de que la conexión existente entre el acceso en condiciones de igualdad y el acceso de acuerdo con los principios de mérito y capacidad aconseja controlar, para evitar una diferencia irracional o arbitraria entre los concursantes, la valoración que haya sido dada a algún mérito en concreto. Esta doctrina se completa con la declaración de que los méritos que sean tomados en consideración no pueden tener una dimensión cuantitativa que rebase el límite de lo tolerable (SSTC 129/07 de 4 de junio y 118/08 de 31 de octubre y STS de 22 de julio de 2009, 4726/04).

Una segunda línea jurisprudencial a la que habremos de referirnos, y cuya cita es relevante para los argumentos utilizados frecuentemente por la jurisprudencia en la resolución de los casos que se plantean en torno al tema objeto de comentario, resulta ser aquella doctrina fijada de forma reiterada por nuestros tribunales que establece que las bases de la convocatoria de un concurso o pruebas selectivas constituyen la ley a la que ha de sujetarse el procedimiento y resolución de los mismos. Consecuencia de la cual, aún cuando en ciertos supuestos la misma ha sido matizada ${ }^{13}$, una vez firmes y consentidas,

12 STC 30/2008 de 25 de febrero.

${ }^{13}$ En efecto, la STS de 14 de Septiembre de 2006 con remisión a otras, estima que sin que esta regla pueda entenderse como de carácter absoluto, puesto que tanto si a dichas bases se las califica de acto administrativo como de disposición general lo inevitable es que tengan que supeditarse al principio de jerarquía normativa, derivado del principio de legalidad, razón por la cual la Jurisprudencia ha señalado que la Administración ha de atenerse, primordialmente, al fijar las mismas a las reglas jurídicas vigentes a la sazón por lo que no puede olvidar el acatamiento de las normas legales de carácter superior. Admitiendo, consecuentemente en algunos casos excepcionales, especialmente en supuestos de violación de derechos fundamentales o de nulidad de pleno derecho, la impugnación de las bases con motivo de la de los actos que ponen termino al proceso selectivo. 
vinculan por igual a los participantes y a la Administración, así como a los Tribunales y Comisiones encargados de la valoración de los méritos, no pudiéndose modificar sino de acuerdo con las previsiones establecidas en nuestra legislación procedimental en los distintos supuestos ${ }^{14}$.

Segunda línea jurisprudencial de la que se extraen, asimismo, dos importantes conclusiones: la primera, que la observancia del principio de igualdad que, también por imperativo constitucional (artículos 14 y $23 \mathrm{CE}$ ), es obligada en todo proceso de acceso a la función pública, lleva inherente la exigencia de que las dudas que se susciten sobre el alcance que haya de darse a las bases o normas de la convocatoria deberán ser interpretadas en un sentido equilibrado que favorezca por igual a todos los aspirantes; y una segunda, consistente en que las normas reguladoras del proceso selectivo han de asegurar a los ciudadanos una situación jurídica de igualdad en el acceso a las funciones públicas, con la inmediata interdicción de requisitos de acceso que tengan carácter discriminatorio (por todas, pueden verse las SSTC 193/1987, de 9 de diciembre, 47/1990, de 20 de marzo, o 353/1993, de 29 de noviembre).

Por último cabe aludir, y no es menos relevante a tenor de los razonamientos que se utilizan de forma frecuente en el supuesto objeto de debate respecto de la posibilidad de que los tribunales puedan o no obligar a la aplicación del artículo 71 de la LPA, a la doctrina relativa a la discrecionalidad técnica de que disfrutan los órganos calificadores y, consiguientemente y con carácter general, la exención de control jurisdiccional sobre la actuación de éstos. Y fruto de la misma, la aceptación, en su actuación evaluadora, de un amplio margen de apreciación que sólo, de forma limitada, puede ser objeto de control y que básicamente se reduce a dos grandes aspectos: el de la inobservancia de los elementos reglados -cuando estos existan- y el del error ostensible o manifiesto ${ }^{15}$;

14 Véase, por todas, la STS de 13 mayo 2010 (rec. núm. 368/2007).

${ }^{15}$ Las Sentencias de la Sala Tercera del Tribunal Supremo de 30 de Noviembre de 2.000 y 27 de Julio de 2.002 establecieron, a estos efectos, unos criterios para hacer posible el control jurisdiccional que pueden resumirse en los siguientes principios: a) la regla general es respetar el cometido de valoración que, en virtud de esa discrecionalidad técnica que es inherente a ellos, corresponde a los órganos calificadores de oposiciones y concursos; b) la revisión jurisdiccional de tal valoración sólo es procedente en supuestos excepcionales, como son los de dolo, coacción o infracción, y ésta última bien sea de las normas reglamentarias que regulan la actuación de tales órganos calificadores, bien de las bases de la convocatoria, c) debe asimismo diferenciarse entre el núcleo material de la decisión técnica, que corresponde en exclusiva a esos órganos técnicos de calificación, y sus aledaños, estando constituidos éstos por la verificación de que se hayan respetado la igualdad de condiciones de los candidatos y los principios de mérito y capacidad de los mismos, lo cual viene a traducirse en la afirmación de que la no ratificación de la propuesta de provisión será también procedente cuando resulte manifiesta la arbitrariedad y, por tanto, evidente el desconocimiento de los principios de mérito y capacidad; d) un indicio de la posible existencia de arbitrariedad 
y, consiguientemente, se excluye de ese limitado control aquellas pretensiones de los interesados que sólo postulen una evaluación alternativa a la del órgano calificador y no estén sustentadas en un posible error manifiesto ${ }^{16}$.

Vemos, pues, que esa discrecionalidad técnica reduce las posibilidades de control de dicha actividad evaluadora, pero desde luego no la excluye y es que, en efecto, la denominada discrecionalidad técnica que corresponde a los órganos calificadores tiene, como uno de sus límites, la observancia del mandato constitucional de la interdicción de la arbitrariedad (artículo 9.3 CE), cuyo reverso positivo es ajustar la actuación administrativa a pautas de racionalidad que sean claramente visibles sin necesidad de los saberes especializados que acotan esa discrecionalidad técnica ${ }^{17}$.

lo constituirá el dato de que, junto a la carencia de cualquier referente objetivo de la valoración que haya sido efectuada de los méritos, concurran elementos que puedan revelar una actuación no suficiente equilibrada del órgano de calificación.

${ }^{16}$ Respecto del "núcleo material de la discrecionalidad técnica" cabe decir, (en este sentido se manifiesta el Tribunal Constitucional en Sentencias, entre otras, de 18 de Abril de 1.989 y 14 de Noviembre de 1.991, y el Tribunal Supremo en Sentencias de 28 de Enero y 21 de Febrero de 1.992), que no corresponde al Órgano Jurisdiccional interferirse en el margen de apreciación otorgado al Órgano de Calificación, ni examinar la medida legal o administrativa para decidir si es la más adecuada o la mejor de las posibles, sino comprobar si no se ha sobrepasado el margen de libertad creando una diferencia de trato irracional o arbitraria entre los evaluados, y ello porque las valoraciones efectuadas por los Tribunales Calificadores, en este concreto ámbito, no son susceptibles de control jurídico como no sean los supuestos, extremos, de desviación de poder o notoria arbitrariedad y entonces sólo para anular las mismas, nunca para sustituirlas por otras.

${ }^{17}$ La STS de 20 de Julio de 2.007 analiza los principios generales sobre la discrecionalidad técnica de que gozan las comisiones calificadoras de oposiciones y concursos, y la inatacabilidad de las bases de dichos procesos selectivos con ocasión de la resolución de los mismos siempre y cuando no hubieran sido recurridas en tiempo oportuno. Con relación al primero de los principios generales el problema que se plantea, no exento de dificultad, es tratar de delimitar con cierta precisión lo que propiamente constituye el núcleo central de la discrecionalidad técnica, pues si bien es verdad que las potestades discrecionales no permiten que, en su ejercicio correcto, se sustituya la valoración del órgano que la tiene atribuida por ninguna otra, no es menos cierto que las exigencias a las que en un Estado de Derecho debe responder la actuación de dichas potestades no las excluye, en su totalidad, del control jurisdiccional sino, únicamente, en dicho núcleo central. En este sentido resulta ilustrativa la Sentencia de la Sala Tercera del Tribunal Supremo de 11 de junio de 1.991, que resume la doctrina existente al respecto del control jurisdiccional de la actuación administrativa, consagrado en el artículo 106.1 de la Constitución, control que se extiende incluso a los aspectos discrecionales de las potestades administrativas, y que viene siendo aplicada por los Tribunales, a través de varias pautas que, como expresa la Sentencia citada, son: 1) El control de los hechos determinantes que en su existencia y características escapan a toda discrecionalidad; 2) La contemplación o enjuiciamiento de la actividad discrecional a la luz de los Principios Generales del Derecho, que informan todo el Ordenamiento Jurídico y por tanto también la norma habilitante que atribuye la potestad discrecional, de donde se deriva que la actuación de esta potestad ha de ajustarse a las exigencias de aquéllos; y 3) El principio de interdicción de la arbitrariedad de los Poderes Públicos, recogido en el artículo 9.3 de la Constitución, que as- 
Pues bien, vistas estas pautas emitidas por nuestros tribunales y que, como hemos puesto de manifiesto, tendrán especial incidencia en los argumentos que se manejan para la resolución de los distintos supuestos planteados, hora es ya de que demos cuenta de la específica doctrina en interés de ley recaída en estos casos y de la divergencia que respecto de su alcance realizan distintos pronunciamientos jurisprudenciales.

\section{La doctrina en interés de Ley recaída sobre el supuesto que nos ocupa: la STS de 4 de febrero de $2003^{18}$.}

La parte recurrente en casación en interés de ley solicitaba de la Sala que se fijase la siguiente doctrina legal: "El trámite de subsanación de defectos a que se refiere el artículo 71 de la Ley de Régimen Furídico de las Administraciones Públicas y del Procedimiento Administrativo Común es plenamente aplicable a los procedimientos selectivos de Profesor Asociado de las Universidades españolas."

El Tribunal Supremo -fundamento de derecho segundo-, y frente a la cuestión suscitada, hacía el siguiente planteamiento del objeto de debate: "En la cuestión examinada, la sentencia impugnada, frente al criterio que mantiene la sentencia de instancia sostiene que el artículo 71 de la Ley 30/92, modificada por la Ley 4/99, no es aplicable a los procedimientos selectivos, pues éstos no se inician a instancia del interesado, rigiéndose por las bases de la convocatoria y si en las mismas se establece un plazo para presentar la documentación que acredite los méritos de los concursantes, no puede permitirse que con posterioridad a la expiración de dicho plazo se aporten nuevos documentos ni podrá el Tribunal dar un plazo de subsanación al efecto, por lo tanto, el Tribunal al dar un nuevo plazo de subsanación en relación con los méritos alegados, infringió lo dispuesto en las bases".

El Tribunal Supremo declarará, a la vista de ese argumento ${ }^{19}$, que desde el

pira a que la actuación de la Administración sirva con racionalidad los intereses generales (artículo 103.1 de la Constitución). Dicho de otro modo, como señala el propio Tribunal Supremo en su Sentencia de 22 de Diciembre de 1.988 , "las limitaciones a la discrecionalidad administrativa en la materia (a salvo la desviación de poder) se refieren al procedimiento por el que se llega a la resolución del concurso y a la apreciación de las condiciones legales de los aspirantes, pero no se extiende a los juicios técnicos de los tribunales calificadores; la valoración de los méritos de los concursantes no tiene otros límites legales que los que, en su caso, se establezcan en las bases de la convocatoria". En definitiva, si bien el Tribunal Calificador goza de amplia discrecionalidad técnica, no cabe duda, de acuerdo con lo expuesto, que la misma debe descansar en el respeto a lo dispuesto en las bases del proceso selectivo.

${ }^{18}$ En análogo sentido se expresará, con posterioridad, la sentencia de 26 de noviembre de 2004 (rec. núm. 161/2004). Asimismo, puede también citarse la sentencia del propio Tribunal de 14 de septiembre de 2.004 (rec. núm. 2.400/99).

${ }^{19}$ La sentencia, con cita de anterior jurisprudencia, argumenta que la tesis de la plena subsanabilidad de los defectos en una oposición o concurso había sido reconocida en la sentencia del Tribunal Supremo 
punto de vista de la doctrina procesal era preciso señalar el carácter gravemente dañoso y erróneo de la sentencia impugnada que vendría determinado por la consideración de sostener la inaplicabilidad a la cuestión debatida del artículo 71.2 de la Ley 30/92, modificada por la Ley 4/99. Frente al criterio de mantener su inaplicabilidad entenderá que debía regir en toda su extensión el principio de subsanación consagrado en el artículo 71 de la Ley, debiendo requerirse al interesado para que pueda subsanar los posibles defectos que pueda contener su solicitud fijando la doctrina legal solicitada ${ }^{20}$.

Sin embargo, es necesario precisar que la doctrina fijada en dicha sentencia, al sentir de un importante sector jurisprudencial al enfrentarse al trámite de subsanación de defectos, era referida tan sólo a la documentación acreditativa de los requisitos exigidos para la participación en un procedimiento selectivo, pero no contenía, con la claridad necesaria, su aplicabilidad a la documentación acreditativa de los méritos que se aleguen. Ese matiz ha llevado a entender, según decimos a una importante línea jurisprudencial asentada en nuestros tribunales, la conclusión de que la mencionada sentencia se refiere tan sólo solo a los supuestos de subsanación de documentos presentados en plazo y que son exigidos como requisito para participar en el proceso selectivo pero no es extensible a los supuestos de subsanación de méritos que abordamos en el presente trabajo ${ }^{21}$.

de 6 de noviembre de 1990 con cita de los derogados artículos 54 y 71 de la Ley de Procedimiento Administrativo, al considerar que era subsanable la omisión, lo que no comporta la infracción de la doctrina jurisprudencial en orden al carácter vinculante de las bases del concurso a las que también se refiere la sentencia impugnada y añade que la subsanación del defecto relativo a la no presentación de documento acreditativo se admite sin problemas en las sentencias de 18 de octubre de 1976, 13 de julio de 1987, 8 de noviembre de 1988, 12 de abril de 1989 y 26 de mayo de 1989 , siendo destacable la sentencia de 16 de mayo de 1983 que hace plena aplicación del artículo 71, en la redacción de 17 de julio de 1958, admitiendo la posibilidad de que la Administración requiera a los firmantes para que en plazo de diez días subsanen la falta que ha sido observada e igual sucede en la posterior sentencia de 28 de junio de 1985, al considerar que es acertada la decisión de la sentencia apelada cuando declara que no se puede atender a un criterio riguroso formalista que es contrario a la voluntad real perseguida por el legislador.

${ }^{20}$ Dirá, de forma expresa, dicha Sentencia que "frente a dicho criterio entendemos que debe regir en toda su extensión el principio de subsanación consagrado en el artículo 71 de la Ley, debiendo requerirse al interesado para que pueda subsanar los posibles defectos que pueda contener su solicitud"

${ }^{21}$ Baste por todas referirnos a la STSJ de Madrid de 29 de julio de 2010 (339/2009) y otras muchas que, respecto del alcance de dicha sentencia, argumentan que Como puede apreciarse sin dificultad, la Sala $3^{\text {a }}$ del Tribunal Supremo admite la subsanación de defectos en la justificación de la experiencia docente porque en el caso que enjuicia, concurren una serie de circunstancias especiales a saber, que la convocatoria sólo exigía, para justificar la experiencia docente previa, una hoja de servicios certificada por el Jefe de personal de la Delegación Territorial de Educación, pero no indicaba el contenido de esa hoja de servicios, ni si en concreto en dicho certificado debía reseñarse el período en el que el aspirante impartió efectivamente docencia, lo que dio lugar a una duda razonable de la interesada sobre el contenido del do- 
¿Es correcta dicha interpretación sobre el alcance de la doctrina fijada? ¿Cabe mantener otra posición alternativa? ¿Deberíamos establecer algún criterio que ayudase a que la casuística que se produce encontrase una solución más allá de dejar su resolución al criterio de cada tribunal? ${ }^{22}$. Lo analizaremos en los siguientes apartados.

\section{LOS DISTINTOS ARGUMENTOS UTILIZADOS PARA VE- DAR O LIMITAR SUSTANCIALMENTE LA POSIBILIDAD DE APLICACIÓN DEL ARTÍCULO 71 LPA}

Efectivamente, y cómo concluíamos al final del anterior epígrafe, matizando esa inicial posición sobre la aplicabilidad del precepto a los procedimientos selectivos, que como hemos dado cuenta fue ratificada con la STS de 4 de febrero de 2003 que fijó doctrina legal sobre la materia, no se puede ocultar la

cumento que acreditaba su experiencia docente, al subsiguiente error y por tanto a la posibilidad de subsanarlo en aplicación de criterios de racionalidad y proporcionalidad, o dicho de otro modo, que la posibilidad de subsanación de la documentación que acredita la experiencia docente de los aspirantes a plazas de profesor, es una excepción, y que la regla es la imposibilidad de subsanar si las bases de la convocatoria no ofrecen dudas sobre su significado y alcance.

${ }^{22}$ Desde luego la opinión del Tribunal Supremo sigue insistiendo en la procedencia de la subsanación. Así la Sentencia de la Sala de lo Contencioso-Administrativo del Tribunal Supremo de 25 de Octubre de 2012 (rec. 1417/2011) establece que:

«Constituye doctrina reiterada de esta Sala y Sección, recogida por todas en nuestra reciente sentencia de 17 de junio de 2011 (casación 2724/2009 , F.D. 5º), así como en las de 20 y 27 de mayo de 2011 (casación 712/2009, F.D. $3^{\circ}$ y $1719 / 2007$ respectivamente) y las que en ella se citan; 10 de junio de 2009 ( cas. 3244/2006 ) y 18 de febrero de 2009 ( cas. 8926/2004) la relativa a que, sin negar el carácter vinculante que poseen las bases de cualquier convocatoria, su interpretación y aplicación debe hacerse siempre en el sentido más favorable a la mayor efectividad del artículo 71 de la Ley 30/1992, este Tribunal mantiene una interpretación amplia del sentido y alcance del precepto en la reciente Sentencia de fecha 20 de mayo de 2011, dictada en el Recurso de Casación 3481/2009, en la que se planteaba un supuesto similar al de autos (la aspirante habían acreditado determinados méritos, pero no constaba la homologación de los cursos como exigían las Bases de la Convocatoria, homologación que fue acreditada por la aspirante sin necesidad de que la Administración requiriera su subsanación), ha dicho que: «Así la Sentencia de fecha 4 de febrero de 2.003 , dictada en un Recurso de Casación en Interés de Ley, admite expresamente que el trámite de subsanación de defectos a que se refiere el artículo 71 de la artículo 71 de la Ley de Procedimiento Administrativo en la redacción de 1958, pues se impone en ambos preceptos el deber de la Administración de requerir al interesado para que se subsanen las deficiencias cuando se aprecie que el mismo no cumple los requisitos que exige el ordenamiento en vigor y como señala en este punto el Ministerio Fiscal, la redacción del apartado segundo del artículo 71 excluye los procedimientos selectivos o de concurrencia competitiva para la ampliación prudencial hasta cinco días del plazo cuando la aportación presente dificultades especiales, luego si se prohíbe dicha ampliación, es claro que el precepto autoriza la concesión del plazo de los diez días cuando se trate de un procedimiento selectivo de concurrencia competitiva, como es el caso planteado». 
existencia de una posición jurisprudencial mucho más restrictiva que con gran cautela, a mi juicio excesiva, reduce la aplicación de dicho artículo utilizando los más diversos argumentos que, en última instancia, pueden reconducirse en el fondo de la argumentación que la sustenta a la prevalente aplicación de los principios de eficacia y seguridad jurídica. Eso sí sin frontalmente declararlo así y reinterpretando, como hemos dado cuenta, el sentido y alcance de la doctrina establecida en la más arriba citada sentencia de nuestro más alto tribunal.

Los argumentos que se vierten para ello son diversos y, desde mi punto de vista, no siempre correctamente utilizados. Analicemos los de mayor calado utilizados para ello.

Hay resoluciones jurisdiccionales que ponen en cuestión la aplicabilidad de dicho artículo por no tratarse de un procedimiento iniciado a instancia de parte ${ }^{23}$. Argumento cuando menos discutible ya que de la dicción del artículo 71 no se deduce, en ningún caso, que éste sea un presupuesto de hecho para su aplicabilidad. Pero es que, por otro lado, es asimismo controvertido mantener que respecto a cada candidato el proceso selectivo sea un proceso iniciado de oficio. Como ya citábamos en una anterior sentencia implícitamente, según lo establecido en el párrafo $2^{\circ}$, el precepto admite su aplicación a los procesos selectivos y es el párrafo $3^{\circ}$, ahora sí, el que se refiere en exclusiva a los procedimientos iniciados a solicitud de interesado.

Otras resoluciones, por su parte, basan su argumentación en la eventual infracción del principio de igualdad ${ }^{24}$. Ciertamente, y no creo que esto admita

${ }^{23}$ Puede verse, a estos efectos, la STS de 11 de mayo de 2009, recurso 613/2005, donde se establece que el tribunal de selección no está obligado a conceder un plazo para subsanar la documentación acreditativa de los méritos, porque "no nos encontramos ante un procedimiento iniciado a instancia de parte, regido por el art. 70 y 71 de dicha Ley, sino ante un procedimiento iniciado de oficio, y además, ante un procedimiento en concurrencia, en este caso selectivo de funcionarios, donde los interesados tienen que acreditar sus méritos dentro de un plazo determinado, por lo que se evidente que, sin necesidad de negar tajantemente la posibilidad de aplicación de dicho precepto en alguna circunstancia, no sea de aplicación en el presente caso (...)".

${ }^{24}$ Puede verse, a este respecto y de acuerdo con la posición que se mantiene, la STSJ del País Vasco de 5 de mayo de 2010 (rec. núm. 656/07) que razona, a mi juicio con acierto, que "Lo que hace la sentencia recurrida es interpretar aquel requisito con un criterio de racionalidad (deducible de lo que dispone el artículo 9.3 de la Constitución ) y ponderar las singulares circunstancias del caso enjuiciado, para, en función de todo ello, permitir que el recurso administrativo sea una posibilidad de completar lo exigido en la convocatoria por apreciar razones que así lo aconsejaban.

Por otra parte, la decisión que adopta, como expresamente señala, es coincidente con el criterio sentado por esta Sala en la sentencia de 11 de octubre de 1991 y representado por la conveniencia de evitar, en los procesos selectivos, exclusiones que puedan resultar desproporcionadas. 
discusión alguna, este principio ha de inspirar inexcusablemente un proceso selectivo. Pero tampoco parece que pueda verse afectado por un trámite de subsanación en que no se alteran las condiciones de participación de los aspirantes dado que el mismo sólo permite atender a lo ya alegado en el tiempo procedimental previamente establecido.

\section{También suelen encontrarse otras que apelan a la discrecionalidad técnica del Tribunal ${ }^{25}$. Y de nuevo aquí nos encontramos con un argumento que pu-}

En relación con lo que antecede, conviene subrayar que ciertamente los participantes en procesos selectivos están obligados a cumplir con las bases de la convocatoria y recae sobre ellos la carga de aportar la documentación en los términos que establezcan dichas bases, ya que así resulta conveniente para que el funcionamiento de esos procesos sea igual para todos los participantes y se desarrolle con la normal regularidad que exige el principio constitucional de eficacia administrativa (artículo $103 \mathrm{CE}$ ).

Pero debe destacarse también que esos criterios de racionalidad y proporcionalidad, que antes se han apuntado, no permiten valorar como incumplimiento de las repetidas bases aquellos comportamientos de los aspirantes que no respondan a una resistencia a observarlas, sino a una razonable duda sobre su significado o alcance. Cuando esto último suceda lo procedente será permitir subsanar el error inicial en que se pueda haber ocurrido.

La existencia de esa duda razonable es de apreciar en el caso enjuiciado y hace que deba considerarse acertada la subsanación que en la vía administrativa permite la Sala de Bilbao.”.

La conclusión a que conduce la doctrina expuesta, a juicio de la Sala, no puede ser distinta de la alcanzada en la instancia: en atención al propio tenor literal de las Bases $6^{\mathrm{a}}$ y $9^{\mathrm{a}}$ era razonable para la aspirante dudar sobre el momento para la aportación de la documentación acreditativa de los méritos en la fase de concurso, por lo que en consecuencia lo procedente era permitir subsanar el error inicial en el que pudo haber incurrido la parte ahora apelada, como entendió el Tribunal calificador en su acuerdo inicial, posteriormente objeto de revisión.

De igual modo que en el caso anterior, lo accesorio es que en el asunto enjuiciado por el Alto Tribunal la posibilidad de subsanación se concediera en atención a la forma de acreditación del mérito alegado, en tanto que en el presente caso la controversia verse sobre el tiempo idóneo para la acreditación, pues en ambos casos lo fundamental es la concesión del trámite de subsanación con fundamento en la redacción ambigua, imprecisa o contradictoria de las Bases, razonablemente generadora de dudas en los destinatarios en cuanto a su significación y alcance.

No se estima infringido, por ello, el principio de seguridad jurídica, ni tampoco el de igualdad, como entiende D. ${ }^{a}$ Delia , al provocar que los aspirantes que limitaron sus alegaciones de méritos a aquellos que podrían acreditar dentro del plazo señalado para la presentación de instancias estén en inferioridad de condiciones respecto de los aspirantes que alegaron todos los que consideraron de su interés.

El término de comparación válido, en el caso analizado, no puede situarse en los aspirantes que, junto a la ahora apelada, participaron en el procedimiento de provisión instrumentado para la cobertura de la plaza convocada. Por el contrario, a juicio de la Sala, debe situarse en todos aquéllos aspirantes a quienes la redacción de las Bases les condujo a una duda razonable sobre el momento establecido en aquéllas para la acreditación de los méritos. Y únicamente éstos, en el supuesto de haber recibido un trato dispar al otorgado a la parte apelada, podrían considerar infringido el derecho a la igualdad que invocan los apelantes.

${ }^{25}$ Puede verse, respecto de esta y su aplicación, en este caso correcta de dicha doctrina, en relación con la temática que nos ocupa la STSJ de Madrid de 26 de marzo de 2009 (rec. núm. 1490/2007) que indica que "SEXTO.- Procede analizar a continuación la pretensión de la actora respecto al error del Tribunal Calificador en cuanto al cómputo en dicha fase de concurso de sus méritos como registradora en la 
diera resultar paradójico. Y es que no se está abordando con la subsanación de los méritos alegados la valoración del mérito con relación a lo establecido en la bases, sino la actividad procedimental dirigida a que los documentos ya aportados por los participantes en un proceso selectivo en tiempo y forma tengan la fiabilidad y los datos suficientes para ser tenidos o no en cuenta como méritos valorables (actividad esta última que sí sería la que constituiría la denominada actividad discrecional del Tribunal).

elaboración de una encuesta sobre salud bucodental en la Provincia de Ciudad Real, el resultado del período probatorio no puede arrojar más que la desestimación de aquella, por cuanto, examinadas de nuevo las Bases, Anexo IIA, en cuanto describe las funciones y tareas principales de los puestos ofertados, "toma y verificación de datos", resulta en el caso de la recurrente, que era la función del odontólogo, precisamente la de trasladar los datos de la salud oral ( tras examinar al escolar en cuestión), al registrador/a, siendo la función de éste/a, la de cumplimentar los datos de la ficha-encuesta, clasificarlos, codificarlos y remitirlos al equipo coordinador para su informatización y explotación de resultados, tareas, que no son precisamente las de toma y verificación de datos ni su posterior preparación y depuración, dado que la misma se limitaba a cumplimentar la ficha-encuesta tras los datos observados y obtenidos por el odontólogo y los remitía al equipo coordinador para su correspondiente informatización.

Por ello y finalmente, no procedía requerimiento alguno de la Administración a través del Tribunal Calificador, pues no puede valorarse como duda de dicho Tribunal la puntuación otorgada por el mismo a los méritos acreditados, ni tiene cabida en el seno de la discrecionalidad de sus funciones un eventual procedimiento de subsanación de errores, cuando la propia convocatoria delimita cuales son los perfiles del puesto ofertado y la documentación que libremente cada aspirante pueda aportar en su favor. Y aún es así, que hemos de admitir, ciertamente, que no siempre es fácil determinar los límites de la inconcusa doctrina sobre la llamada discrecionalidad técnica de la que gozan los Tribunales de oposiciones o de valoración de conocimientos o méritos concretos. Pero pese a ello hemos de significar la no discutida realidad de dicha doctrina e, incluso, el hecho de que la misma afecta a la propia potestad jurisdiccional que se actúa en un proceso como el que nos ocupa, (control de legalidad conforme a la exigencia Constitucional del artículo 106 de la "Lex Prima"), al comportar o reconocer "de facto" una parcela en cierta medida, nada desdeñable por cierto, inmune a dicho control lo que, se podría aducir, podría suscitar recelos desde la óptica de la contrariedad al derecho a la tutela judicial que ha de ser efectiva. Sobre esta cuestión resulta particularmente esclarecedora la doctrina establecida por el Tribunal Supremo en Sentencia de 21 de Febrero de 1.992 y en la que razona: "Siendo el instrumento de conocimiento que utilizan los Órganos Jurisdiccionales la técnica jurídica, su facultad de intervenir en las decisiones de las Comisiones o Tribunales calificadores es plena cuando han infringido o inaplicado normas en las que todos los elementos son reglados, como pueden ser las de procedimiento o las que regulan determinadas titulaciones, de modo que valoradas éstas expresamente en el Baremo, sólo quien las ostente conforme a su régimen específico puede recibir la puntuación correspondiente a las mismas. Pero caso bien distinto es el de aquellas partes del Baremo en las que los méritos no tienen una referencia normativa estricta, sino que su grado de valoración se encomienda al Órgano calificador, dentro de unos límites prefijados.

Es aquí donde la discrecionalidad técnica despliega toda su eficacia, en el sentido de que la Jurisdicción no puede sustituir el criterio de la Administración por el simple hecho de que considere que hubo una defectuosa evaluación del mérito de que se trate, puesto que si así fuere tendríamos que llegar a la conclusión de que su capacidad para enjuiciar lo sometido a la discrecionalidad técnica sería igual a la del Órgano especialmente encargado de apreciarla. Se necesita algo más que una simple divergencia de criterio con el sostenido por el Órgano calificador y este elemento complementario viene expresado por la quiebra del principio de igualdad en el trato o atribución de puntuaciones arbitrarias o desproporcionadas. 
Pero inclusive se utilizan otros adicionales a los ya comentados. A saber: que el alcance del precepto se circunscribe a los requisitos para participar, pero no a los méritos alegados por los participantes ${ }^{26}$, que sólo cabe subsanar los de-

Recientemente, en Sentencia de 28 de Enero de 1.992, nos referimos a la tentativa del Tribunal Constitucional para marcar el límite entra las facultades de un Órgano calificador, con la capacidad técnica para valorar unas pruebas, y la posibilidad de controlar jurídicamente lo resuelto por el mismo en función del principio constitucional de igualdad. Señalábamos, en efecto, cómo la Sentencia 215/1.991, de 14 de Noviembre, se hace un encomiable intento para distinguir entre el núcleo material de la decisión técnica, reservado en exclusiva a las Comisiones juzgadoras, y sus aledaños, constituidos por la verificación de que se haya respetado efectivamente la igualdad de condiciones de los candidatos y de los principios de mérito y capacidad de los mismos en el procedimiento de adjudicación de las plazas, si bien, a la postre este esfuerzo dialéctico concluye en la jurídicamente más asequible afirmación de que la disconformidad con el criterio de aquéllas sólo puede producirse cuando resulta manifiesta la arbitrariedad de la adjudicación efectuada y, por tanto, evidentes el desconocimiento del principio de igualdad de mérito y capacidad para el acceso a las funciones públicas consagradas en los artículos 23.2 y 103.3 de la Constitución".

${ }^{26}$ Puede leerse dicha consideración en la STSJ de Andalucía (Sala de Granada) de 29 de septiembre de 2008 (rec. núm. 3106/2003) o en la STSJ de Madrid de 29 de julio de 2010 (rec. núm. 339/2009) o en la STSJ del País Vasco de 23 de noviembre de 2010 (rec. núm. 333/09). Lo que tampoco parece pueda ser la interpretación correcta sobre el alcance de la aplicación del artículo 71 de la LPA a los procesos selectivos ya que, respecto de la subsanación de los requisitos para participar, ya existe un trámite específico como son las listas provisionales de admitidos y excluidos (artículo 20 del RD 364/1995, de 10 de marzo por el que se aprueba el Reglamento General de Ingreso del Personal al Servicio de la Administración General del Estado y de Provisión de Puestos de Trabajo y Promoción Profesional). Más adecuada a la debida interpretación, siempre según nuestro punto de vista, resulta ser la STSJ de Andalucía (Sede Granada) de 25 de octubre de 2010 que argumenta que "En este sentido debemos considerar que la solución adoptada por el tribunal resulta contraria a derecho y errónea en cuanto que ante la falta de valoración del curso en su totalidad por las razones expuestas el Tribunal pudo y debió hacer uso de la facultad de subsanación del art. 71 de la ley 30/92. Esto resulta en cuanto que aún cuando resulta claro a tenor de la convocatoria que el aspirante tiene la carga de alegar los méritos que le asistan en el presente proceso selectivo en el momento de presentación de la solicitud, el cual se alza como el término preclusivo en el cual deberá proceder al ejercicio de su derecho en el supuesto de autos resulta de aplicación el indicado artículo 71.1 de la Ley 30/1992, de 26 de noviembre, de Régimen Jurídico de las Administraciones Públicas y del Procedimiento Administrativo Común en cuanto que en este caso no se trata de que el recurrente trate de hacer valer un mérito nuevo no acreditado con anterioridad de tal forma que se pretenda la valoración ex novo de un mérito en su momento no alegado en el momento oportuno.

Debe distinguirse en este punto el momento de ejercicio del derecho, de la posible corrección que pudiera hacer el interesado del derecho que se hizo valer en el momento de presentación de la solicitud. De acuerdo con las bases existe un único momento oportuno para hacer valer los méritos por parte de los aspirantes: el de presentación de las solicitudes. La ley 30/92 reconoce la posibilidad de subsanar deficiencias que pudieran afectar a la solicitud cursada y los meritos alegados. Resulta en todo caso inviable la posibilidad de alegar y acreditar nuevos méritos con ocasión de una pretendida mejora de la solicitud o subsanación de defectos pues debe claramente distinguirse la alegación de un merito ex novo, de la corrección de deficiencias que pudieran existir en la acreditación de méritos oportunamente alegados.

En el presente supuesto la documentación inicial y oportunamente aportada por la recurrente acreditaba la realización del curso de que se trata de tal forma que si el Tribunal consideraba que no todos los módulos de los cursos resultaban valorables por no estar relacionados con el temario al no especificarse el número de horas correspondientes a módulos que si resultaban valorables conforme señala el propio Tri- 
fectos de carácter formal pero no aquellos que tengan carácter sustantivo ${ }^{27}$, la superior validez de las bases de la convocatoria que han sido aceptadas por los participantes ${ }^{28}$, o, por hacer una última alusión a un argumento también utilizado, la de que no pueden imputarse a la Administración los errores propios cometidos por los participantes ${ }^{29}$.

bunal, debió requerir de subsanación al interesado pues la susceptibilidad de valoración de los cursos resultaba de la documentación oportunamente alegada por el Tribunal de tal forma que no se trataba de valorar ex novo un mérito qu no hubiese sido oportunamente alegado, sino de precisar o matizar un mérito que el recurrente había alegado y acreditado en tiempo y forma si bien al juicio del tribunal de forma insuficiente al no desglosar las horas correspondientes a cada uno de los módulos. Por tanto en el supuesto de autos no se trata de que se acrediten unos méritos cualitativamente diversos de los inicialmente probados sino de matizar los ya acreditados por el recurrente y cuya necesidad de matización resulta de la decisión del mismo Tribunal de no valorar el curso en su totalidad, decisión y consecuente necesidad que escapaba a las previsiones del recurrente al presentar su solicitud en el proceso selectivo. Así pues debe anularse la resolución impugnada a fin y retrotraer el procedimiento a fin de que por el tribunal de valoración se someta a su criterio técnico la valoración de los módulos de que se trata conforme a la documentación acompañada por el recurrente en la fase de alegaciones, valoración que resulta vedada a esta Sala de conformidad con el art 71.2 de la LJCA ante la imposibilidad de suplantar la discrecionalidad del Tribunal de valoración por no ni contarse con elementos de juicio suficientes para el ni existir una solución inequívoca a tal valoración".

${ }^{27}$ Argumento utilizado por la sentencia objeto de comentario que, por otro lado, no aclara cuáles han de ser considerados con una u otra naturaleza lo que nos sumerge de nuevo en un campo abonado a la especulación

28 Argumentación que estimo, de nuevo, que no es de aplicación. Las bases de la convocatoria efectivamente son la "ley del concurso", pero no alcanzo a ver porqué no se puede aplicar un trámite procedimental como la subsanación ni tampoco, como hacen algunas Administraciones, excluir expresamente en las mismas la subsanación en contra de lo establecido en el artículo 71 de la LPA. Las bases también están sujetas al principio de jerarquía normativa. La STS de 31 de mayo de 2011 (rec. núm 3892/2009), a propósito de esta cuestión, argumenta que "La tesis de la Administración - que mantenía la que las bases de la convocatoria son la ley del concurso y no recurridas por la participante obligaban a presentar los documentos traducidos- responde a una lectura de las Bases de la Convocatoria y de los artículos 70 y 71 de la Ley 30/1992 en exceso literalista, que no se adecua a la interpretación del mismo en el sentido más espiritualista reflejado en nuestra Jurisprudencia".

${ }^{29}$ Razonamiento, el de la propia torpeza, que aunque ingenioso (y que inclusive ha sido utilizado en sentido contrario por alguna jurisprudencia) no es a mi juicio de aplicación si lo ponemos en relación con la finalidad que apunta el precepto objeto de estudio y la doctrina legal fijada por el Tribunal Supremo. $\mathrm{Y}$ es que si, ciertamente, es una carga que pesa sobre el participante en el proceso selectivo (así lo indica la STSJ de Andalucía, Sala de Granada, de 15 de junio de 2009, rec. núm. 1948/03), y de ahí que los no alegados en tiempo y forma no pueda ser valorados, no creo que tal consideración pueda extenderse a que cumplida esa carga los defectos u omisiones no puedan ser subsanados lo que claramente pugnaría con el principio de justicia material. Distinto es el caso, y aquí si se puede alegar el error propio, que se plantea cuando el participante en el proceso selectivo adjunta un certificado de otro organismo público, erróneamente emitido, en que consta un período trabajado inferior y que es valorado correctamente según lo que refleja ya que la diligencia que cabe exigir al aspirante impide valorar un mérito no alegado aún cuando sea cierto (STSJ de Castilla-León de 11 de marzo de 2005, rec. núm. 375/2003). 
Estos son, en suma, los argumentos mas frecuentemente utilizados que, como se ha intentado poner de manifiesto en los comentarios y notas a pié de página que nos preceden, parecen admitir cuando menos una réplica. Por ello que la cuestión sea otra ¿Existen argumentos a favor de la aplicabilidad del precepto? Me temo que sí y, en mi opinión, de mayor enjundia y peso específico que los anteriormente analizados. Veámoslos, pues, seguidamente para tratar de alcanzar alguna conclusión válida a la cuestión planteada en este trabajo.

\section{UNA LECTURA ALTERNATIVA DEL PREGEPTO EN SU APLICACIÓN A LOS PROCESOS SELEGTIVOS}

Como creo que ha quedado suficientemente nítido de la exposición realizada hasta el momento, no se trata aquí de la subsanación, en cualquier caso, de méritos no aportados en tiempo según las bases de la convocatoria o que pudieron haber sido subsanados debidamente porque existía un plazo para ello ${ }^{30}$. Ciertamente no me cabe duda de que han de concurrir dudas razonables y circunstancias ciertamente singulares como indica alguna jurisprudencia para proceder a la subsanación ${ }^{31}$, pero también creo que hay suficientes razones para corregir, vía artículo 71 LPA, posibles deficiencias en los documentos aportados, errores materiales ${ }^{32}$, ausencia de compulsas en documentos aportados ${ }^{33}$,

\footnotetext{
${ }^{30}$ Como sucede, inclusive, no ya con los méritos sino también con los requisitos para la participación en el proceso selectivo. Véase la STSJ de Granada de 1 de julio de 2009 (rec. núm. 2088/03).

${ }^{31}$ Así lo subraya la STSJ de Madrid de 19 de octubre de 2010 (rec. núm. 3743/08), si bien no parece que el criterio de circunstancias excepcionales o dudas razonables pueda ser el acogido por la STSJ de Madrid de 30 de septiembre de 2010 ( $\left.N^{\circ} 443 / 08\right)$ que hace prácticamente evanescente, con esa argumentación, la subsanación prevista en el artículo 71 LPA al considerar que, respecto de un certificado presentado, pero en el que no constaban las fechas de toma de posesión y cese, procedía la no valoración del mérito aportado. Si esto es así ¿qué grado de aplicabilidad tiene el artículo 71 LPA? ¿En qué pugnaba la igualdad de los participantes en el proceso selectivo con haber valorado, tras su subsanación por el Tribunal, el mérito alegado en el momento procedimental oportuno? ¿Quién es el causante de la duda o el error?. Sin embargo, y en un caso prácticamente idéntico (tampoco constaban la fecha de toma de posesión y de cese), la STSJ de Castilla-La Mancha de 10 de noviembre de 2009 (rec. núm. 839/2005) accede a dicha subsanación.

${ }^{32}$ Como acontece en la STSJ de Madrid de 3 de marzo de 2011 (rec. núm. 884/09) en que el encabezamiento de un certificado aparecía la propia aspirante, pero el mismo estaba debidamente firmado por el responsable de la unidad competente para certificar.

${ }^{33}$ De sumo interés es, a este respecto, la STS de 5 de marzo de 2007 (rec. núm. 214/2002) que expone que: "SEXTO.- Sobre las cuestiones suscitadas por los demás motivos hemos de decir que la Sala de La Coruña no ha infringido las bases de la convocatoria. Al contrario, ha hecho valer la interpretación procedente de las mismas sin que en esa tarea haya llegado a sustituir a la Administración en el ejercicio de facultades discrecionales, como lo demuestra que le haya devuelto las actuaciones para que resuelva ella misma el concurso-oposición valorando los méritos del Sr. Juan Ramón .

$\mathrm{Al}$ proceder de esa manera, no ha vulnerado el artículo 46 , ni ninguno de los otros preceptos mencionados por el Sr. Luis Angel y el Ayuntamiento de Vigo.
} 


\section{o cualesquiera otras circunstancias ${ }^{34}$, que tratándose de vicios formales -que no de fondo o sustanciales como confunde alguna jurisprudencia citada en la}

El primero no ha sido infringido porque, en realidad, no se ha llegado a discutir sobre la autenticidad de los méritos del Sr. Juan Ramón avalados por fotocopias sin compulsar. Ese extremo no ha estado en cuestión. De lo que se ha debatido es de si procedía o no aceptarlas como documentación acreditativa que, como sabemos, es lo que exigían las bases para avalar esos méritos. El Tribunal Calificador, sencillamente, prescindió de las fotocopias presentadas por el Sr. Juan Ramón sólo porque no estaban compulsadas sin hacer ninguna otra objeción a las mismas. Sin embargo, tal carencia, en el contexto del concurso-oposición que nos ocupa no tenía por qué comportar por sí sola la ineficacia de ese medio de prueba. De ahí que la Sentencia recurrida considerase riguroso en exceso tal criterio, pues entendió que, si no las consideraba suficientes, debió hacer uso de sus facultades de comprobación, precisamente, en atención a lo dispuesto, además de por la Base IX, por el artículo 46.2 y 3 de la Ley 30/1992 .

Por eso, la Sala de La Coruña subraya las condiciones en las que la Sentencia de este Tribunal Supremo de 26 de octubre de 1994 (apelación 8078/1992), alegada en la contestación a la demanda, consideró ajustado a Derecho el rechazo de unas fotocopias sin compulsar: se trataba de un proceso selectivo en el que no fueron aceptadas después de que el interesado tuviera la oportunidad de corregir el defecto y no la aprovechara. A lo que cabe añadir que la Sentencia de 28 de noviembre de 1998 (casación 3545/1994) aceptó como prueba una fotocopia no compulsada cuya autenticidad no fue impugnada por el Abogado del Estado. Y que, más recientemente, la Sentencia de 30 de noviembre de 2006 (casación 4980/2003 ) ha considerado contrario a Derecho el proceder de la Administración consistente en rechazar una fotocopia no compulsada sin requerir al interesado su subsanación si es que no la tenía por válida. Pronunciamientos todos ellos que confirman la corrección de la solución seguida por la Sala de instancia.

Los restantes preceptos mencionados, los artículos 2 y 4 c) del Real Decreto 896/1991 ; 15, 16 y 44.5 del Real Decreto 364/1995, 19.1 de la Ley 30/1984 y 91.2 de la Ley 7/1985 , tampoco han sido vulnerados porque, tiene razón el Sr. Juan Ramón, coinciden en someter los procesos de selección del personal para las Administraciones Públicas a los principios de igualdad, mérito y capacidad, conforme a las bases establecidas al efecto y nada en la Sentencia impugnada los pone en cuestión. Mejor dicho, en tanto restablece la interpretación de estas últimas que deriva de sus previsiones y se ajusta al artículo 46 de la Ley 3071992 , asegura que, efectivamente, sean la ley del concurso-oposición. Es decir, hace que el convocado por el Ayuntamiento de Vigo se desarrolle con arreglo a lo que señalan para que, así, el Tribunal Calificador determine cuál de los candidatos es el acreedor a la plaza objeto del mismo por mérito y capacidad. Por lo demás, está claro que la Sentencia de La Coruña no abre una nueva fase de presentación de documentos, ya que se limita a recordar el cauce que el Tribunal Calificador tiene para hacer las comprobaciones que considerase necesarias, cosa bien distinta.

En cuanto a la Sentencia n ${ }^{\circ} 481 / 1998$, debemos comenzar señalando que ella misma precisa cuál es el objeto del enjuiciamiento que lleva a cabo en términos positivos y negativos. Positivamente, dice que el proceso al que puso fin tenía como objeto determinar si se había infringido el derecho fundamental reconocido en el artículo 23.2 , lo que suponía comprobar si a alguno de los demás participantes en la convocatoria se le aceptaron fotocopias sin compulsar mientras se le rechazaban al Sr. Juan Ramón . Así, lo que decía esa Sentencia es que tal extremo no se había probado y, por eso, desestimó el recurso. Negativamente, porque advertía que no correspondía examinar en aquella ocasión las infracciones a la legalidad ordinaria y, en particular, a lo previsto en las bases, que pudieran haberse producido.

En consecuencia, ambas Sentencias de la Sección Primera de la Sala de La Coruña, aunque se ocupan del mismo acto administrativo a instancias del mismo recurrente, lo hacen desde perspectivas diferentes y, por eso, no entran en contradicción ya que no la hay entre afirmar que no se ha demostrado la infracción del derecho fundamental a acceder a la función pública en condiciones de igualdad conforme a las leyes porque no consta una desigualdad en el trato dado a los participantes y mantener, al mismo tiempo, que no se respetaron las bases del concurso en lo relativo a qué debe entenderse por documentación acreditativa de 
calificación de los mismos- su no subsanación pugnaría con el principio de justicia material y con una correcta interpretación del alcance del principio de igualdad y del contenido del artículo 23 de la CE. En definitiva, creo que es razonable y preciso distinguir entre alegación del mérito y acreditación del mismo y es, en este último aspecto, donde ha de determinarse el alcance de la aplicación del artículo 71 de la LPA ${ }^{35}$.

Razones creo que hay suficientemente para ello. Demos cuenta de ellas.

A) Principio de inderogabilidad singular: los artículos 51 y 52 LPA y la aplicabilidad del artículo 71 LPA en sentido amplio al supuesto que nos ocupa.

Como hemos tenido ocasión de comentar uno de los argumentos de los que se parte, a fin de no admitir la subsanación que se solicita, parte de la superior autoridad de las bases de la convocatoria y su respeto por todos los intervinientes en el proceso selectivo. Creo que nada hay que oponer respecto de la vigencia y la utilidad de este clásico paradigma en los procesos selectivos. Otra cosa es que el mismo tenga un alcance absoluto y, por ello, no es menos cierto que, como con ocasión de otros supuestos ha sucedido, el mismo también puede y debe ser matizado en este punto. El contenido del artículo 71 de la LPA no puede ser dejado sin efecto por una norma de rango reglamentario o cualquier otra disposición administrativa ${ }^{36}$. No cabe, por decirlo de una vez, hacer

los méritos alegados. Esa diferente aproximación excluye, por tanto, que se haya producido una desigualdad en la aplicación de la Ley".

${ }^{34}$ A título de ejemplo, y de la un tanto errática doctrina jurisprudencial que comentamos, la STSJ de Castilla-La Mancha de 3 de septiembre de 2007 (rec. núm. 191/2006), sin embargo, admite no ya la subsanación de algún error en el documento aportado, sino inclusive el derecho de subsanación cuando lo que se acompaña es la solicitud de dicho mérito a otro organismo.

35 Así lo realiza con acierto, desde mi punto de vista, la STS de 28 de abril de 2006 que, tras distinguir entre acreditación de requisitos preceptivos de participación y de méritos valorables, argumenta que la clave está en la alegación y acreditación, aún defectuosa, del mérito de cuya valoración se trate que, en este caso, siendo evidente para el tribunal su defectuosa acreditación por razón de la lengua en que fue expedida la correspondiente certificación sin que, pese a ello y a las reclamaciones de la recurrente, ni siquiera resueltas, se le concediera plazo para la correspondiente subsanación, la mera interpretación literal de la nota tercera del Anexo I de las bases de la convocatoria, en que se funda la Administración, es desproporcionada a la finalidad de la propia convocatoria y al sentido del art. 36 de la Ley 30/92.

${ }^{36}$ Así lo establece expresamente la STSJ de Madrid de 19 de mayo de 2005 que indica "Y por ello la Sentencia de la sala Tercera del Tribunal Supremo anula la norma reglamentaria por cuanto se está limitando los derechos o situaciones jurídicas favorables al administrado establecidos por una Ley -en este caso, la posibilidad procedimental de subsanar la no aportación inicial de un documento preceptivo para evitar una declaración de inadmisión-, y porque, también está rompiendo la coherencia interna del orde- 
depender la aplicabilidad o no del artículo 71 de lo que las Bases tengan a bien disponer ${ }^{37}$. Tampoco cabe, a mi juicio, que su alcance puede ser interpretado en forma restrictiva ya que, precisamente, el espíritu de éste es justamente lo que impide ${ }^{38}$.

Razonamiento que se mantiene y que tiene como inmediata consecuencia que deba ser excluida, o al menos no tenida en cuenta, cualquier disposición de las bases de la convocatoria que anulen un derecho consagrado por el ordenamiento jurídico pues las bases de la convocatoria, ya se consideren disposición administrativa o acto administrativo, no reúnen rango jerárquico suficiente para hacer inaplicable el mismo ${ }^{39}$.

namiento que, cual directriz interna, viene predeterminada por la anterior norma con rango de Ley, pues ambas normas -ley y reglamento- constituyen dos instrumentos normativos pero que se integran en único cuerpo dotado de unidad interna; esto es, no solo por su subordinación de rango, sino por su necesaria coherencia con el sistema establecidos en la norma legal..."

${ }^{37}$ Como erróneamente, desde mi punto de vista, establece la STSJ de Cantabria de 14 de octubre de 2008 (rec. núm. 600/2007).

${ }^{38}$ La STS de 20 de mayo de 2011 (rec. núm. 3.481/2.009) califica de "literalista" una interpretación restrictiva que no se corresponde con el espíritu del precepto. Esa visión amplia se consolida desde la STS de fecha 14 de septiembre de 2004 (rec. núm. 2400/1999 y se ratificó en SSTS de fecha 4 de mayo de 2009 (rec. núm. 5279/2005 ), 31 de diciembre de 2009 (rec. núm. 1842/2007) y 28 de septiembre de 2010 (rec. núm. 1756/2007).

${ }^{39}$ Así lo estima, con coherencia difícil de rebatir, la Sentencia del Tribunal Superior de Justicia de Galicia de 27 de febrero de 2013 (rec. 5/2013) que explica en su Fundamento Quinto .- En este punto, hemos de precisar que la Sentencia apelada y la Administración se aferran a la Base Decimoquinta de la convocatoria que dispone al ocuparse de las Normas sobre cumplimentación de instancias: "Al consignar las peticiones, cualquier dato omitido o consignado erróneamente por la persona interesada no será susceptible de subsanación y no podrá ser invocado por ésta a efectos de futuras reclamaciones, ni considerar por tal motivo lesionados sus intereses y derechos. Finalizado el plazo de solicitudes por ningún concepto se alterará su petición, ni aún cuando se trate del orden de prelación de las plazas solicitadas. Cuando los códigos resulten ilegibles, estén incompletos o no se coloquen los datos en la casilla correspondiente se considerarán no incluidos en la petición y no serán subsanables, perdiendo todo derecho a ellos los concursantes".

Estamos ante una cláusula de estilo en las convocatorias de esta naturaleza, que por su carácter de concurrencia masiva, unido al tratamiento informático, y para evitar rectificaciones caprichosas o extemporáneas, declara la insubsanabilidad absoluta de las instancias.

Pues bien, señalaremos que una convocatoria, en cuanto acto administrativo general es inidónea para excluir de plano la posibilidad de subsanación de las solicitudes por contravenir los términos e interpretación del art. 71 de la Ley 30/1992. Las cláusulas universales de exoneración de responsabilidad no solo no tienen cabida en el ámbito de los consumidores sino que no son admisibles en relación a los usuarios de servicios públicos o administrados puesto que la negación automática y de plano de toda posibilidad de subsanación afecta directamente al derecho a una resolución motivada y con ello, indirectamente se lesionaría al derecho a la tutela judicial efectiva del art.24 de la Constitución, ya que malamente podrá controlarse si la decisión final de la Administración es motivada y congruente si se negó la posibilidad de alegar y probar en vía administrativa lo que realmente se pedía. 
B) Principio de proporcionalidad y racionalidad de la actuación administrativa en la apreciación del mérito y la capacidad de los participantes ${ }^{40}$.

No parece que pueda haber duda de que la exclusión de la subsanación, en todo caso y sin matices, parecería contrario a la necesaria proporcionalidad en la actuación administrativa y la racionalidad que debe imperar en la aplicación de requisitos formales, sobre todo cuando, como en el caso acontece, se dificulta con dicha opción la apreciación del mérito y la capacidad de los participantes.

De esta forma, no parece que haya que poner en cuestión que los participantes en procesos selectivos están obligados a cumplir con las bases de la convocatoria, y que además recae sobre ellos la carga de aportar la documenta-

Una cosa es que los datos consignados sean vinculantes para los solicitantes y que no admitan rectificación por razones de oportunidad o por error interpretativo exclusivo del participante (supuestos en que la Administración y la Sala admite la válida aplicación de tal estipulación Decimoquinta), y otra muy distinta cerrar el paso a la posibilidad de rectificación o subsanación cuando la propia Administración ha contribuido a forjar el error por unas bases ambiguas o ha provocado con sus propios actos la confianza legítima en la aspirante para después defraudarla ( supuestos en que no puede oponerse la citada estipulación Decimoquinta). De los términos de las bases y la solicitud, no tenemos duda de la buena fe y lectura de las bases por parte de la recurrente en el sentido de que consignando la casilla como "Itinerante" no estaba renunciando a otros destinos distintos en Galicia sino al contrario, extendiendo su solicitud a la eventualidad de que tales plazas fueren calificadas como "itinerantes". Y como tal buena fe fue propiciada por la propia actuación de la Administración ( eludiendo la predeterminación de las plazas con tal carácter) y por las propias bases (ningún inciso expresamente avala la interpretación de exclusividad por el solo hecho de rellenar tal casilla), hemos de estar a los esenciales principios pro actione y pro cives en la vertiente de interpretación mas favorable para la efectividad del derecho al acceso a cargos y empleos públicos del art.23.2 CE que se proyecta también en promoción y concursos de movilidad. Y en consecuencia, se imponía facilitar la subsanación o rectificación, sin limitarse la Administración a escudarse en una aplicación leonina de las Bases o en la fría tecnología informática que si no es supervisada bajo pautas de sensibilidad puede conducir a injusticias clamorosas.

${ }^{40}$ Principios plenamente aplicables a estos supuestos. Y así lo hace el Tribunal Supremo que en Sentencia de fecha 4 de mayo de 2009 (Recurso de Casación 5279/2005), desestimó un recurso de casación contra una Sentencia que aplicó el art. 71 Ley 30/1992 en un recurso administrativo y sostiene (Fundamento de Derecho Tercero) que: «La infracción denunciada no puede ser compartida, ya que el razonamiento que la Sala de instancia ha seguido no significa ignorar o desatender el carácter vinculante de las bases de la convocatoria.

Lo que hace la sentencia recurrida es interpretar aquel requisito con un criterio de racionalidad (deducible de lo que dispone el artículo $103 \mathrm{CE}$ ).

Pero debe destacarse también que esos criterios de racionalidad y proporcionalidad, que antes se han apuntado, no permiten valorar como incumplimiento de las repetidas bases aquellos comportamientos de los aspirantes que no respondan a una resistencia a observarlas, sino a una razonable duda sobre su significado o alcance. Cuando esto último suceda lo procedente será permitir subsanar el error inicial en que se pueda haber ocurrido.» 
ción en los términos que establezcan dichas bases. Y es que, sin duda, si así resulta conveniente para que el funcionamiento de esos procesos sea igual para todos los participantes y se desarrolle con la normal regularidad que exige el principio constitucional de eficacia administrativa, distinto parece ignorar de forma absoluta los criterios de racionalidad y proporcionalidad que han de regir la actividad administrativa ${ }^{41}$. Criterios de actuación que, como antes se ha apuntado, no permiten valorar como incumplimiento de las repetidas bases aquellos comportamientos de los aspirantes que no respondan a una resistencia a observarlas, sino a una razonable duda sobre su significado o alcance y, cómo concluye alguna jurisprudencia, cuando esto último suceda lo procedente será permitir subsanar el error inicial en que se pueda haber incurrido ${ }^{42}$.

En definitiva, cuando es manifiesta la desproporción entre el defecto advertido, ya se trate de la ausencia de algún dato o de alguna verificación exigida a los documentos que se aportan, y la consecuencia que se produce - no va-

\footnotetext{
${ }^{41}$ Así lo hace la Sentencia del Tribunal Superior de Justicia de Galicia de 27 de febrero de 2013 (rec. 5/2013) que argumenta en relación a dichos extremos que:

Pues bien consideramos que la Administración ha actuado con rigidez y rigor desproporcionado en las concretas circunstancias del caso.
}

A) La voluntad material de la recurrente de obtener destino en Galicia, desde su actual destino en Toledo, es incontrovertida y se deriva del hecho concluyente de solicitar nada menos que 190 plazas en la Comunidad gallega. Igualmente, es patente que el carácter de "itinerancia" no lo alzaba la recurrente como condición necesaria, lo que se deriva de un dato cuantitativo y cualitativo. El dato cuantitativo de que resultaría prácticamente imposible que las 190 plazas fueren itinerantes dado el carácter especial y casi excepcional de las mismas. Y el dato cualitativo de que la propia naturaleza de tales destinos, sometidos a unas condiciones de movilidad y carga transitoria o inestabilidad, restan su apetencia al común de los funcionarios, con lo que es difícil adivinar que razón objetiva puede alguien tener para optar exclusivamente a las plazas itinerantes y no a las ordinarias.

B) La voluntad formalizada de la recurrente se asienta en estampar la marca en la quinta casilla destinada a "Código de itinerancia" para todas las plazas indicadas.

C) Así la discordancia entre la "voluntad real" y la "voluntad declarada" tiene la naturaleza de error. $\mathrm{Y}$ tal error es padecido por la recurrente.

Pues bien, con carácter general, los errores padecidos por los aspirantes al cumplimentar las convocatorias cuyos términos son claros y completos, deben ser soportados por aquéllos, y sin que la Administración tenga que brindar plazos de subsanación cuando se enfrenta a una voluntad declarada en términos que puede seguir el procedimiento hacia la decisión final, aunque pudiere derivar hacia resultados no apetecidos por quien cometió el error.

Sin embargo, y aquí radica la singularidad del presente caso, es pacífico y aceptado por la Administración (y declarado en la sentencia apelada) que al tiempo de la convocatoria y durante el plazo de formular solicitudes no se habían determinado ni conocido las plazas que tenían carácter itinerante. O sea, la aspirante ha de tomar la decisión de optar a las plazas sin un dato esencial, cual es si las mismas tienen o no carácter itinerante.

42 STSJ de Madrid de 19 de octubre de 2010 (rec. núm. 3743/08) y STS de 14 de septiembre de 2004 (rec. núm. 2400/1999) 
loración de un mérito que concurre de forma efectiva en el participante- lo procedente será subsanar el error padecido.

Pero es más, desde mi punto de vista, no sólo en el supuesto de la existencia de una duda razonable en cuanto al contenido de los documentos que deben ser aportados por los participantes se debe dar lugar a admitir dicha subsanación. No faltaría más en estos casos. Es que inclusive, y precisamente en base a dichos principios, también debe admitirse en caso de ausencia de requisitos formales aunque los mismos no dejasen dudas al respecto pero su entidad fuera menor, como la ausencia de un sello de inscripción ${ }^{43}$, o la falta de un visto bueno a un certificado por un órgano o funcionario ${ }^{44}$. En general, y al menos desde mi punto de vista, deben ser tuteladas las pretensiones de los participantes en los distintos procesos selectivos para el ingreso a la función pública de que sean tenidos en cuenta los méritos que alegaban cuando existan cualesquiera omisiones ${ }^{45}$, eso sí siempre que hubieran sido aducidos y justificados documentalmente en el momento establecido ${ }^{46}$, aunque esa justificación hubiera de ser aclarada o subsanada ulteriormente. Desde la posición que se mantiene, en todos esos casos, no estamos sino ante requisitos exigidos que deben ser calificados como de subsanables respecto de la solicitud inicial.

C) Infracción de la confianza legítima y la buena fe de los participantes.

$\mathrm{Y}$ es que, en efecto, en ocasiones con tal proceder también se pueden infringir los citados principios. Y se produce cuando la confianza legítima de los aspirantes, unida a los propios actos de la Administración (convocatoria oscuras y difícilmente interpretables en un único sentido), colocan a los aspirantes en un escenario de incertidumbre que es determinante para inducir al mismo a la comisión de un error en la presentación de las acreditaciones o en lo que realmente se solicita sin ofrecerle la posibilidad de subsanar o aclarar la posible ambigüedad de su solicitud o la acreditación del mérito respectivo, con el fin de que en el plazo de subsanación al efecto, pueda confirmar los extremos requeridos, ya se trate de aclarar lo que se solicita, ya la de acreditar aquellos extremos insuficientemente alegados ${ }^{47}$.

\footnotetext{
${ }^{43}$ STS de 10 de junio de 2009 (rec. núm. 3244/2006).

${ }^{44}$ STS de 24 de enero de 2011 (rec. núm. 344/2008).

45 Así se afirma de forma expresa en la STSJ de Madrid de 3 de diciembre de 2010 (rec. núm. $960 / 2.007)$.

46 STSJ de Castilla y León de 18 de enero de 2004 (rec. núm. 2556/2004).

${ }^{47}$ Así lo hace la Sentencia del Tribunal Superior de Justicia de Galicia de 27 de febrero de 2013 (rec.
} 


\section{D) La interpretación del término "legislación aplicable" contenida en el artículo 71 LPA.}

Ya se ha apuntado cómo, en ocasiones, la jurisprudencia que niega la subsanación de los documentos acreditativos de los méritos de los participantes alude a la solicitud de iniciación, y a los requisitos de ésta establecidos en el artículo 70, para justificar la no posibilidad de subsanación de los mismos. Creo, sinceramente, que una correcta interpretación del artículo 71 LPA exige hacer hincapié en la totalidad del texto del precepto que no sólo prevé la subsanación respecto de los requisitos establecidos en el artículo 70, sino de todos aquellos que resulten de la legislación específica aplicable al caso concreto que es objeto de tramitación.

5/2013) que indica que este proceder de la Administración resulta sorprendente y anómalo; anómalo por menoscabar la seguridad jurídica, ya que el derecho elemental de quien toma la decisión de cambiar de destino profesional es saber las características esenciales de las plazas a que opta, o sea, conocer de antemano las opciones, expectativas y metas previsibles; sorprendente, ya que al tiempo de la convocatoria al menos existe un núcleo de plazas vacantes cuya oferta puede saberse con certeza y en cambio la Administración parece optar por reservarse para un momento ulterior a la preclusión del plazo de solicitudes, la determinación de las plazas y los adjudicatarios ( ello sin perjuicio claro está, de que pudieran incorporarse posteriormente vacantes sobrevenidas $\mathrm{u}$ otras incidencias).

Esta singular circunstancia convierte la opción de la recurrente expresando su aparente interés en plazas únicamente "itinerantes" en una solicitud de contenido imposible como imposible sería la adjudicación de plazas inexistentes, ocupadas o no ofertadas. Además tal situación es imputable a la Administración porque brinda un tipo de plazas (itinerantes) que posteriormente no serán ofertadas.

En esas condiciones el principio de confianza legítima de los aspirantes ( posibilidad de ofertarse plazas "itinerantes") unido a los propios actos de la Administración (la convocatoria se ocupa de la forma de cumplimentar las solicitudes de itinerancia, sin aclarar durante el plazo de instancias qué plazas de las distintas especialidades tenían tal carácter), colocan a la aspirante en un escenario de incertidumbre que llevaba al menos, a que si finalmente ninguna plaza tiene carácter itinerante ( y siendo patente la voluntad material de obtener destino en Galicia) a ofrecerle la posibilidad de subsanar o aclarar la posible ambigüedad de su solicitud, con el fin de que en el plazo de subsanación al efecto, pueda confirmar los términos de su apetencia ( si exclusivamente quería destinos de "itinerancia" o cualquier otra plaza de otro carácter, siempre que una u otra estuviese en Galicia).

Si la Administración finalmente hubiere declarado la existencia de tan sola una plaza de itinerancia en la especialidad de la recurrente (aunque la hubiera obtenido preferentemente otro aspirante) podría sostenerse que no vulneró la confianza legítima de aquélla y que su instancia era potencialmente idónea para aceptando las reglas del juego competitivo, optar a la misma. Pero no es el caso, puesto que la Administración ofrece un escenario de potencial oferta de plazas itinerantes, que lleva a la solicitante a solicitar nada menos que 190 plazas para enfrentarse posteriormente a la negativa absoluta de plazas con tal carácter.

Y sigue indicando en el Fundamento Sexto que: Bajo tales premisas y volviendo al caso de autos, hemos señalado que la recurrente ha actuado de buena fe, bajo la confianza legítima sentada por la Administración (art.3 de la Ley 30/1992, de 26 de Noviembre, de Administraciones Públicas) y ésta no ha actuado con la diligencia exigible, ya que ni indicó durante el plazo de instancias las plazas itinerantes ( art.73.3 , 78.1 y 89 Estatuto Básico del Empleado Público), ni brindó plazo de subsanación ( art.71 Ley 30/1992 ) cuando se percató de que ninguna era de la especialidad de la recurrente. 
Parece obvio que el precepto, no podría hacerlo tampoco ya que la materialización de una reserva de ley sólo compete al bloque de constitucionalidad, no se refiere con el término legislación aplicable a una Ley en sentido formal. Con el término legislación aplicable, en mi opinión, el precepto se refiere al sistema normativo que rige el concreto procedimiento de que se trate en el que, precisamente en razón de que las bases de la convocatoria son la denominada "ley del concurso", han de entenderse incluidas éstas. De esta forma, no parece sino que deba concluirse que los requisitos exigidos para la valoración de los méritos aportados por los participantes en el momento procedimental oportuno, y no sólo para la admisión de los participantes ya que respecto de éstos ya existe un trámite específico previsto en la normativa de acceso al empleo público, se incluyen en la ratio del precepto lo que determina su necesaria subsanación.

E) La aplicación al caso planteado de los derechos de los ciudadanos en sus relaciones con la Administración: los artículos 35 e) y f) de la LPA.

Asimismo, es de tener en cuenta que, de nuevo, y aún cuando las bases de la convocatoria establezcan las consideraciones que estimen oportunas en orden al desarrollo del proceso selectivo, las mismas encuentran un límite en el propio ordenamiento jurídico y, por consecuencia, no pueden hacer inaplicables en los procedimientos de selección los derechos de los ciudadanos establecidos en el sistema normativo y, en concreto, respecto del caso que nos ocupa los artículos 35 e) y f) de la $\mathrm{LPA}^{48}$.

En efecto, como sabemos, por una parte, el artículo 35 e) establece el derecho de formular alegaciones y a aportar documentos en cualquier fase del procedimiento anterior al trámite de audiencia -se entiende que sin vulnerar el principio de igualdad que rige en los procedimientos competitivos-, que deberán ser tenidos en cuenta por el órgano competente y, por otra, el apartado f) del artículo 35 de la Ley 30/1992 reconoce que el ciudadano tiene derecho a no reiterar la presentación de una documentación que ya se encuentra en poder de la Administración actuante ${ }^{49}$. Ni la sumisión a las bases de la convocatoria de los participantes en el proceso selectivo, que es una cosa bien distinta

${ }^{48}$ Afirmación de su aplicabilidad que no siempre está presente en la jurisprudencia. Puede verse, en este sentido, la STSJ Extremadura de 14 de marzo de 2006 (rec. núm.16/2004).

${ }^{49}$ Así se realiza en la SSTS de 18 de febrero de 2009 (rec. núm. 8926/2004) y de 27 de mayo de 2010 (rec. núm. 1719/2007) o en la STSJ de Madrid de 3 de diciembre de 2010 (rec. núm. 960/2.007). Así esta última sentencia alude a que "Debe recordarse que este artículo 35 f) de la Ley 30/1.992, al igual que 
y que no justifica prescindir del resto del ordenamiento jurídico, ni el argumento subyacente en otras resoluciones jurisdiccionales de que ello suponga un grave obstáculo y una gran dificultad para la Administración en el desarrollo del proceso selectivo, parece que puedan hacer inaplicables estos derechos ${ }^{50}$. Cómo decimos, eso sí y sin restricciones, siempre que no se vulnere el principio de igualdad.

F) La aplicación del precepto debe obedecer a la mayor efectividad del derecho fundamental contenido en el artículo $23 \mathrm{CE}$.

No sólo la solución que se propugna no es contraria al contenido del principio de igualdad de los participantes en el proceso selectivo, sino que, precisamente, la interpretación del precepto en el sentido indicado no hace sino dar mayor efectividad al contenido material del derecho fundamental contenido en el artículo 23 CE, es decir, el acceso en condiciones de igualdad al empleo público de acuerdo con el mérito y la capacidad de los participantes ${ }^{51}$, aserto este último que no quedaría garantizado si méritos alegados en plazo por los participantes fuesen desestimados por no reunir algún requisito formal.

Desde nuestro punto de vista tal actuar, obviando o no constatando la realidad de los hechos ${ }^{52}$, desconocería los principios de mérito y capacidad en una

el artículo 71 tantas veces citado del propio Cuerpo Legal, contienen una manifestación del principio "pro actione" del que está imbuida toda la Ley procedimental,- que, como es sabido, se configura como una norma claramente antiformalista donde se pretende primar el acierto y la justicia material de la decisión administrativa -, cual es la utilización de distintos medios, dirigidos a conseguir aquel objetivo, y que no es otro que el flexibilizar los trámites de los procedimientos administrativos, de tal manera que los defectos formales que afecten a las actuaciones del interesado no supongan la pérdida irreversible de las posibilidades de hacer valer su derecho, no pudiendo perderse de vista que aunque, es cierto que las Bases de la convocatoria de un proceso selectivo constituyen la auténtica ley por las que el mismo debe regirse, es obvio que tales Bases no existen aisladas del resto del Ordenamiento jurídico, al cual deben acomodarse y conforme al cual deben siempre interpretarse e integrarse".

50 Así lo resuelve la STS de 20 de abril de 2009 (rec. núm. 4522/2005), bien es cierto que el TS también razona que el derecho de no aportar documentación que ya esté en poder de la Administración, cuando se trate de una organización dotada de personalidad única, no se podrá hacer valer ante toda la Administración, sino sólo respecto de la que actúa.

${ }^{51}$ La Sentencia de 18 de febrero de 2009 (rec. núm. 8926/04) señala que la interpretación y aplicación de las bases de la convocatoria debe hacerse siempre en el sentido más favorable a la mayor efectividad del artículo 23.2 CE y, en consecuencia, deberá ser rechazada cualquier aplicación de las mismas que conduzca a un resultado que no sea compatible con el derecho reconocido en el precepto constitucional que acaba de mencionarse

52 Actuación favorecedora de constatar la realidad de los hechos por parte de la Administración que, asimismo, avala el propio Artículo 39 bis -introducido por la Ley 25/2009- y el artículo 41 LPA. 
interpretación favorable a los mismos del artículo $23 \mathrm{CE}$ respecto del supuesto objeto de análisis y, como indica alguna jurisprudencia, estaríamos ante un supuesto de aplicación desproporcionada, no justificada objetivamente y que conduce, finalmente, a un supuesto de discriminación ${ }^{53}$.

\section{A MODO GONGLUSIVO: ¿ARBITRIO O ARBITRARIEDAD JUDICIAL?}

El Profesor NIETO ha puesto de manifiesto algo que por sabido no es menos oportuno recordar aquí. Afirma dicho autor que los paradigmas tradicionales de funcionamiento de la justicia no sirven para explicar el verdadero fun-

${ }^{53}$ Es la opinión que mantiene la STS de 27 de enero de 2010 (rec. núm. 5955/2007) que, junto a considerar que la desestimación de dichos méritos puede ser objeto del procedimiento especial en materia de derechos fundamentales, subraya que la doctrina constitucional exige que la "interpretación y aplicación que se haga de la normativa aplicable a las pruebas de acceso a la función pública, se haga sin producir situaciones discriminatorias no justificadas objetivamente, o desproporcionadas -art. 14 y 23.2 - o que, conduzcan al desconocimiento de los principios de mérito y capacidad -art. 103.3, CE -, o que pueda tacharse de arbitraria, pues la Sra. Inocencia había aportado a lo largo de las actuaciones prueba documental bastante para que se aplicaran a su favor los méritos previstos en la base tercera, punto 3.1.b) y 2.1.2 de la convocatoria, pues en contra de lo que se dijo en la sentencia como razón de ser de la decisión a que llegó, el estudio y enjuiciamiento de la interpretación que se hizo por la Administración de la indicada base y elementos probatorios, sí que constituía una cuestión susceptible de ser enjuiciado a través del procedimiento especial de amparo judicial de los arts. $114 \mathrm{sgs}$. de la LJCA, pues la posible actuación arbitraria de la Administración al interpretar las bases de la convocatoria y la prueba aportada para reconocer la existencia de hechos acreditativos de la interpretación propugnada por el concursante, podía afectar al mérito y capacidad -art. 103.3 , - del concursante, y a los arts. 14 y 23.2, de la CE, en cuanto que tal postura administrativa llevaba a evitar el juego de esos principios constitucionales, de inexorable observancia según el TC, y a situar en una postura desigual y objetivamente desproporcionada al que como la recurrente pretendía aducirlos, frente a los demás concursantes, que según dijo la actora en la demanda (página 12) se les había aplicado el baremo y valorados los méritos, hay que entender, que justificaba, según la base tercera, punto 3.1.b) <<un informe de vida laboral y copia de contratos que detallan la categoría profesional en lo que se prestaron los servicios $>>$. Dado que forzosamente debe calificarse de arbitraria la actuación administrativa, reflejada al resolver la alzada, de no considerar bastante la documental aportada al respecto por la actora, porque no se presentaba un certificado oficial de la empresa, o porque el informe de la vida laboral reflejaba una cotización a la Seguridad Social no correspondiente a la categoría de Auxiliar, siendo así que el examen atento de dicha documental sí refleja que durante el periodo que va desde el 1 de Diciembre de 1974 al 31 de Mayo de 1996, la entonces actora había cotizado por el epígrafe 07, correspondiente a auxiliar, en empresas del grupo Uralita, y en las fechas anteriores desde 1971, en otras empresas quizá no pertenecientes a ese grupo empresarial, pero que la actora dice eran similares realizando funciones de auxiliar y la Secretaria de la SS (folio 45 exp.), admite al informar que eran asimilables a la reclamada. Sin que, según puede comprobarse por la literalidad de la base, en la misma se diga que la acreditación no pueda hacerse mediante la prueba de que el contrato fuera verbal y no suscrito en contrato oficial. Ello en una interpretación favorable al actor, para dar efectividad al derecho fundamental del art. 23.2.CE, que no ha de olvidarse actúa, con la mayor intensidad en el momento de acceso a la función pública (Subsanación 37)". 
cionamiento de ésta última ${ }^{54}$. Es decir, y por resumir con brevedad la posición de dicho autor, que concebir la función judicial como mera aplicación de la ley no se ajusta a la realidad. Que no nos es posible aprehender el funcionamiento del Derecho, y más que ello, su aplicación práctica en los tribunales de justicia, si no aceptamos la existencia de un arbitrio judicial (actividad lícita) que ha de deslindarse de la arbitrariedad (actividad ilícita).

Ciertamente no creo que estemos ante un supuesto de arbitrariedad en la aplicación de la doctrina en interés de ley citada. También soy consciente de la diversa casuística que se plantea a propósito de la actuación de los tribunales en estos supuestos y de la dificultad de establecer criterios uniformes para todos los casos que habitualmente se plantean. Igual podría decirse de la necesidad de adoptar medidas para agilizar, en la medida de lo posible, la ejecución de los procesos selectivos. Y, asimismo, también soy conocedor de los mecanismos procesales existentes en nuestro ordenamiento para reconducir sentencias divergentes dictadas en supuestos idénticos.

Ahora bien, al menos en la misma medida estimo que se ha puesto de relieve la carencia de un razonablemente exigible criterio uniforme en la aplicación de la institución de la subsanación en méritos presentados por participantes en procesos selectivos y, como consecuencia de ello, la existencia de sentencias contradictorias para supuestos similares cuando no idénticos. Ello a pesar de la doctrina legal de la que se dio cuenta oportunamente. De ahí también, y como propuesta a considerar, la oportunidad de articular un trámite de subsanación para méritos alegados por los participantes en los supuestos que han sido objeto de comentario que bien podría quedar recogido en las normas procedimentales que articulan los procesos selectivos en nuestro ordenamiento jurídico. Ningún bien jurídico creo que sería puesto en cuestión por esa medida -inclusive así se prevé en numerosas convocatorías a través de una calificación provisional-, que reconduciría, en forma más cierta en mi opinión, la actuación judicial a un lógico y comedido arbitrio siempre necesario en la aplicación del ordenamiento jurídico.

54 NIETO, A., El arbitrio judicial, Ariel, Barcelona, 2000. Asimismo, resulta conveniente la consulta de TOLIVAR ALAS, L., Derecho administrativo y poder judicial, Tecnos, 1996. 